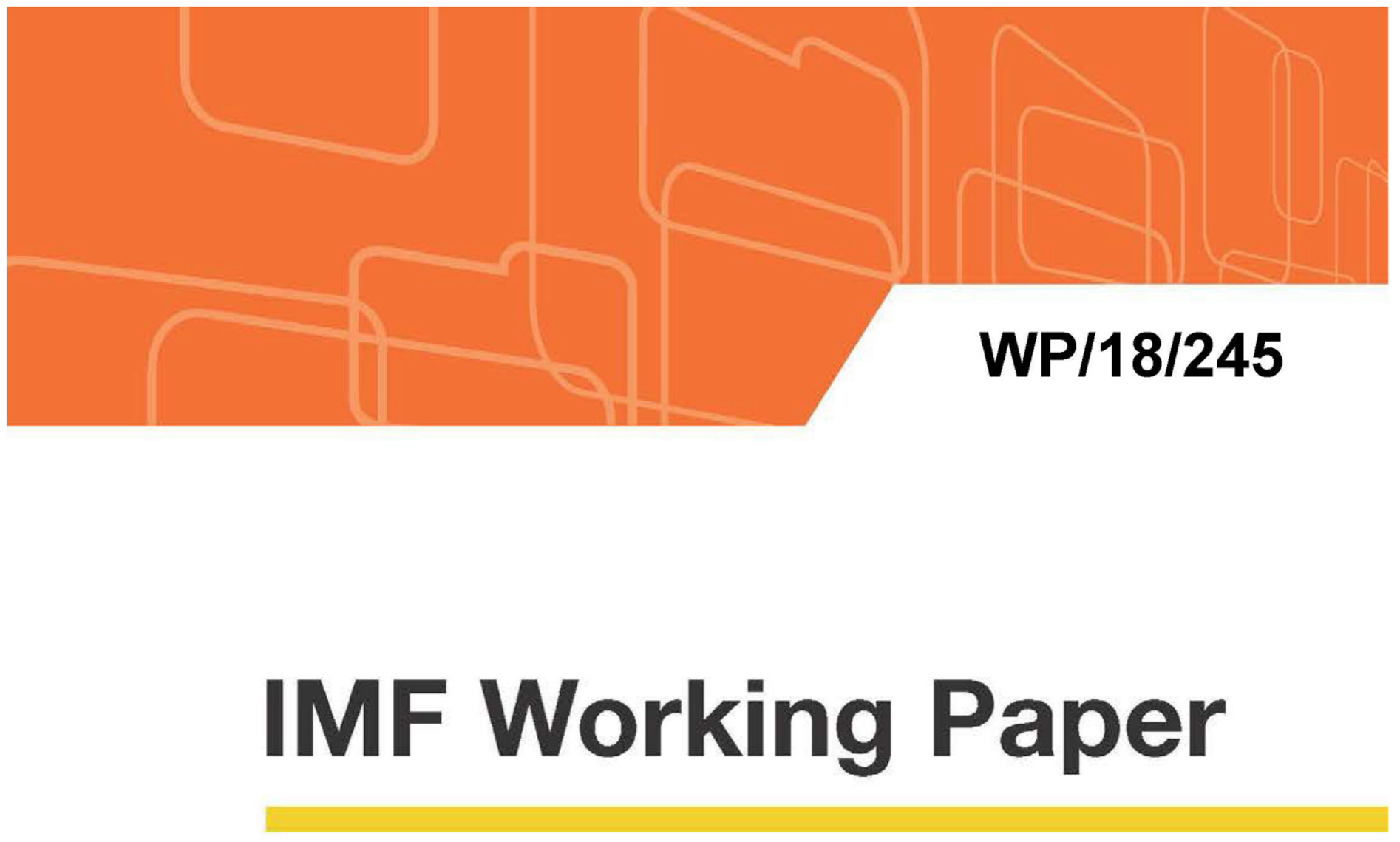

\title{
Populism and Civil Society
}

by Tito Boeri, Prachi Mishra, Chris Papageorgiou, Antonio Spilimbergo

IMF Working Papers describe research in progress by the author(s) and are published to elicit comments and to encourage debate. The views expressed in IMF Working Papers are those of the author(s) and do not necessarily represent the views of the IMF, its Executive Board, or IMF management. 


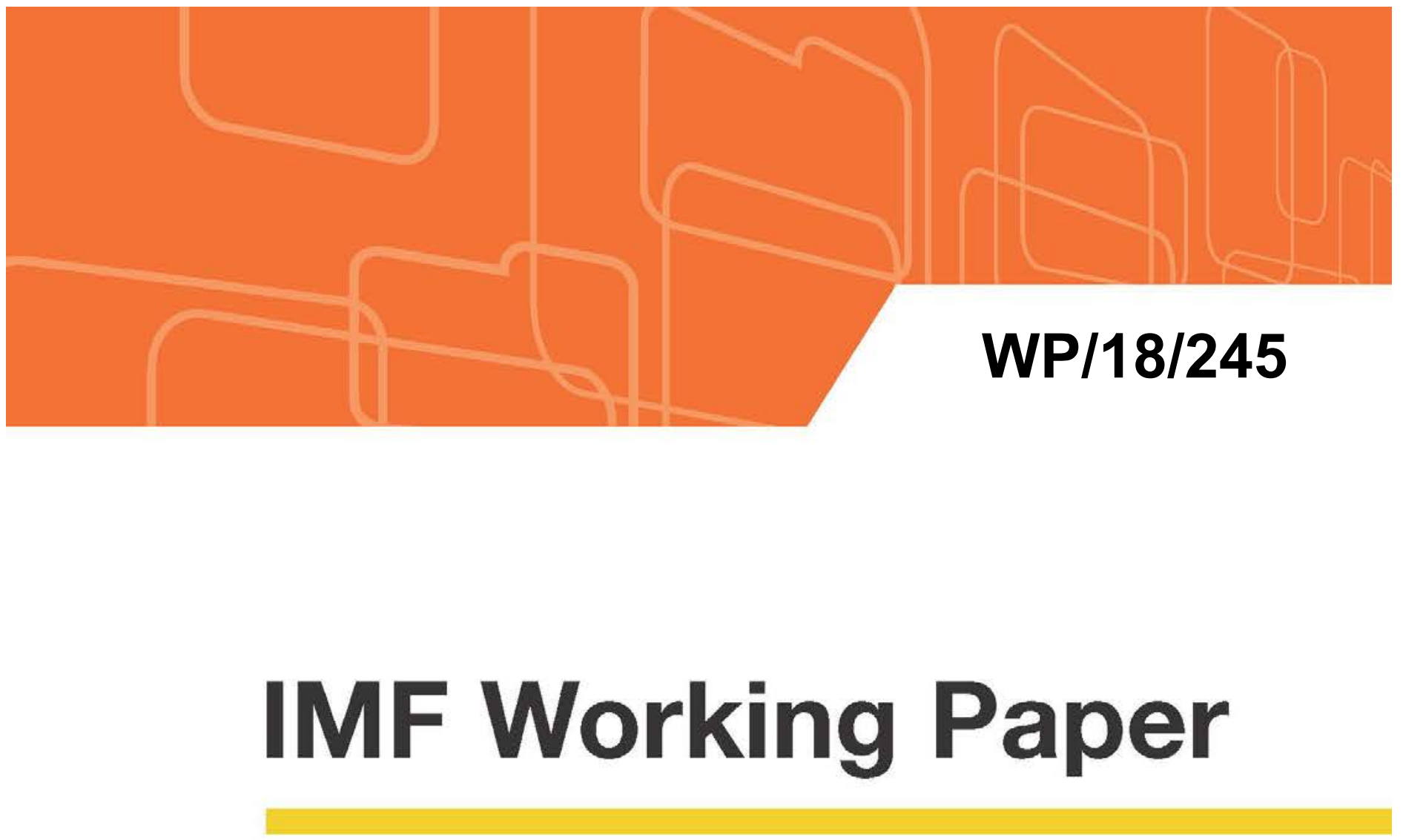

\section{Populism and Civil Society}

by Tito Boeri, Prachi Mishra, Chris Papageorgiou, Antonio Spilimbergo

IMF Working Papers describe research in progress by the author(s) and are published to elicit comments and to encourage debate. The views expressed in IMF Working Papers are those of the author(s) and do not necessarily represent the views of the IMF, its Executive Board, or IMF management.

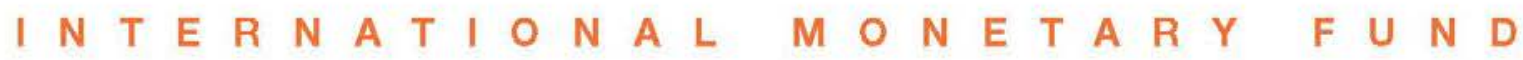




\title{
IMF Working Paper
}

Western Hemisphere Department

\section{Populism and Civil Society}

Prepared by Tito Boeri, Prachi Mishra, Chris Papageorgiou, Antonio Spilimbergo

Authorized for distribution by Jonathan D. Ostry (RES) and Krishna Srinivasan (WHD)

November 2018

\begin{abstract}
IMF Working Papers describe research in progress by the author(s) and are published to elicit comments and to encourage debate. The views expressed in IMF Working Papers are those of the author(s) and do not necessarily represent the views of the IMF, its Executive Board, or IMF management.
\end{abstract}

\begin{abstract}
Populists claim to be the only legitimate representative of the people. Does it mean that there is no space for civil society? The issue is important because since Tocqueville (1835), associations and civil society have been recognized as a key factor in a healthy liberal democracy. We ask two questions: 1) do individuals who are members of civil associations vote less for populist parties? 2) does membership in associations decrease when populist parties are in power? We answer these questions looking at the experiences of Europe, which has a rich civil society tradition, as well as of Latin America, which already has a long history of populists in power. The main findings are that individuals belonging to associations are less likely by 2.4 to 4.2 percent to vote for populist parties, which is large considering that the average vote share for populist parties is from 10 to 15 percent. The effect is strong particularly after the global financial crisis, with the important caveat that membership in trade unions has unclear effects.
\end{abstract}

JEL Classification Numbers: P16.

Keywords: Democracy, voting, populist parties, associations, Europe, Latin America.

Author's E-Mail Address: Tito Boeri (Bocconi University and CEPR) tito.boeri@unibocconi.it; Prachi Mishra: pmishra0513@gmail.com; Chris Papageorgiou cpapageorgiou@imf.org; Antonio Spilimbergo aspilimbergo@,imf.org. 


\section{TABLE OF CONTENTS}

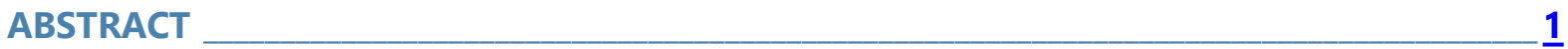

I. LITERATURE REVIEW ________

II. LITERATURE REVIEW _________

III. DATA_____________________________________________________

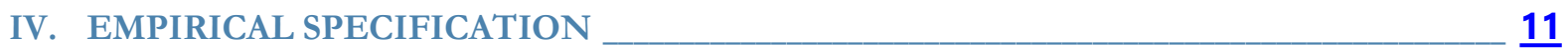

V. EMPIRICAL RESULTS _______ 12

VI. POPULISTS IN POWER __________________________________

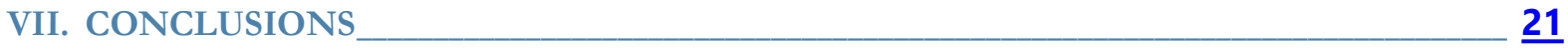

REFERENCES ____ 20 


\section{Literature Review ${ }^{1}$}

Populism is not new. Waves of populism have spread through Russia and the U.S. at the end of the $19^{\text {th }}$ century and through several European and Latin American countries in the $20^{\text {th }}$ century (Mudde and Kaltwasser, 2017; Müller, 2016; Judis, 2016.) ${ }^{2}$ In previous episodes, populism remained marginal (like in Europe in the second half of the $20^{\text {th }}$ century) or became dominant in weak democracies (like Latin America.) What is peculiar about the recent wave is that populism has spread and sometimes became dominant in countries with well-established liberal democracy. This begs the question of how populism not only co-exists but even thrives and prospers in liberal democracies.

What is populism? Populism has been defined in various ways and is often used as a derogative term in political debates. In line with a common view in political science, we use the definition of populism as "an ideology that considers society ultimately separated into two homogeneous and antagonist groups, 'the pure people' versus the 'corrupt elite" (Mudde, 2004.) The key issue of interest here is that the populist ideology considers the people as a monolith, and populist leaders claim to have the monopoly of political representation of the people. This monopoly on representing "the people" is almost a moral right which delegitimizes all other parties, associations, and groups in the populist discourse. In the populist view, a (corrupt and detached) elite is in opposition with the (homogenous and virtuous) 'people.' In the populists' Manichean view, there is no intermediate space between the 'virtuous people' and the corrupt elites. This view is in contrast with the concept of liberal democracy.

Liberal democracies are political systems based on pluralism where different groups represent different interests and values, which are all legitimate provided they respect the rules. In liberal democracies, multiple political parties compete in free elections, branches of government are separated, and a system of checks-and-balances exists. Associations are formed to organize and give voice to these different values. Associations play a key role in liberal democracies. Alexis de Tocqueville in his Democracy in America (1835) writes on the role of associations in democracies:

\footnotetext{
${ }^{1}$ Tito Boeri tito.boeri@unibocconi.it; Prachi Mishra pmishra@,imf.org; Chris Papageorgiou cpapageorgiou@imf.org; Antonio Spilimbergo aspilimbergo@imf.org. We are grateful to Nina Wiesehomeier and Kirk Hawkins for sharing with us their datasets on populist parties in Latin America, populist presidents, and prime ministers in power. Zidong An and Henrique Barbosa for superb research assistance. We also thank Olivier Blanchard, Andrea Ichino, Dennis Quinn and participants at the IMF and the 2018 AEA meetings for insightful comments and suggestions. The views expressed in this study are the sole responsibility of the authors and should not be attributed to the International Monetary Fund, its Executive Board, or its Management.

2 Throughout the paper we use Latin America and Europe as a shortcut for countries in these continents. Individual countries had different experiences with liberal democracy and populism.
} 
"Americans of all ages, all conditions, all minds constantly unite. ... Thus, the most democratic country on earth is found to be, above all, the one where men in our day have most perfected the art of pursuing the object of their common desires in common and have applied this new science to the most objects. Does this result from an accident or could it be that there in fact exists a necessary relation between associations and equality? ... all citizens are independent and weak; they can do almost nothing by themselves, and none of them can oblige those like themselves to lend them their cooperation. They therefore all fall into impotence if they do not learn to aid each other freely. If men who live in democratic countries had neither the right nor the taste to unite in political goals, their independence would run great risks, but they could preserve their wealth and their enlightenment for a long time; whereas if they did not acquire the practice of associating with each other in ordinary life, civilization itself would be in peril. ... The morality and intelligence of a democratic people would risk no fewer dangers than its business and its industry if the government came to take the place of associations everywhere. ... In democratic countries, the science of association is the mother science; the progress of all the others depends on the progress of that one." This citation illustrates well the role of associations in well-functioning liberal democracies. In sum, liberal democracies are pluralistic and associations are key to aggregation; in contrast, populists consider 'the people' as a homogeneous group, which cannot be divided.

But what is the role of associations if the populist leaders are the only legitimate representative of the people? This paper looks at the issue of single individuals' preferences in a large sample of European and Latin American countries. Are individuals who belong to associations more prone to vote for populist parties? Did the global economic crisis and the Euro area crisis change this relation?

We test the hypothesis on whether belonging to a body in civil society (by belonging to a civil society association or a trade union) reduces the probability to vote (as stated in retrospective questions) for a populist party. We use several waves of the European Social Survey (ESS), which comprises more than 60,000 individual observations, covering 17 European countries with populist parties for about 15 years, and several waves of LatinBarometro, which covers all major Latin American countries for several years.

Our main finding is that individuals belonging to associations are less likely to vote for populist parties. In Europe, individuals belonging to associations are 3.2 percent less likely to vote for populist parties during the post global financial crisis period. The result is driven specifically by membership in civil associations rather than trade unions. The finding is robust controlling for several variables that could 
co-determine jointly the voting behaviour in favour of populist parties and the decision to join an association, and removing outliers to estimate a 2-step Heckman model that accounts for the probability of participation in voting. We find qualitatively similar results for Latin America, where voting is compulsory, albeit with very limited data that precludes conducting several robustness checks. We interpret the findings as associations provide ideological anchors, identities, and voice mechanisms,.; as individual beliefs became more unhinged from ideological anchors post-crisis, people felt more open to voting for new parties. Another interpretation is that associations promote social responsibility and acts as a protective shield against populism. Finally, it is not only that association members are less likely to vote for populist parties, but there is also some suggestive evidence for trade union density to be lower in countries where populists have been in power.

This paper makes contributions in three fields. First, our approach is useful in explaining one of the puzzles that populism is generally not correlated to economic crisis (Kriese and Pappas, 2015). For instance, despite the deep economic crisis, Ireland and Iceland did not have strong populist movements. On the other hand, Poland, which did not experience a recession during the global financial crisis, has a party classified as populist in power. We investigate how the presence (or absence) of civil society can explain these differences across countries.

Second, there is an ongoing debate about the importance of economic versus cultural and social factors in explaining the rise of populism (Inglehart and Norris, 2016). Our approach focusing on the intermediate bodies argues that these factors need to be complemented as the spread of populist ideas depends on the presence of a civil society.

Third, our results provide indirect evidence for the old idea that populism may be the response of a society losing its 'collective consciousness.' The idea, which is old in sociology, is that a society needs a system of solidarity between individuals (Durkheim, 1893; Arendt, 1973) providing cross-cutting social ties. When this system breaks down, individuals feel anomia and are ready to support new movements. According to this view, populists gain support after big shocks only if the society does not have enough intermediate institutions which provide an 'ideological anchor' to individuals.

The paper is organized as follows. Section II reviews the literature on populism and economics with a focus on the effect of the recent global financial and euro crises. Section III describes the data sources used in the empirical analysis and takes a first look at these data. Section IV discusses the empirical strategy followed by Section V that reports and discusses the results. Section VI looks at what happens to trade union membership when populists gain power. Section VII draws conclusions. 


\section{Literature Review}

The literature on the causes and the electoral success of populism is old (Ionesco and Gellner, 1969; Di Tella, 1965) and voluminous, but so far answers have been elusive to historians and political scientists (Hawkins et al., 2017). ${ }^{3}$ In this paper, we focus on three questions on which economists have focused: 1) what is the role of populism in rich postmodern societies and why has populism been on the rise even before the global financial crisis? 2) what are the effects of the global financial crisis and, in particular, the euro crisis on politics? 3) why do voters vote for parties which are ultimately against their own interest?

\section{Populism in post-modern societies}

The rise of populist parties in Europe since the 1980s has revived the literature on populism in political science. The success of (far right) populist parties in the last thirty years has been remarkable. With the Green Parties, the populist far right parties are the only new party family in Europe in the last seventy years and the only one to spread consistently in both Eastern and Western Europe. The reasons for the rise of populist parties are complex, involving both demand and supply factors (Mudde, 2007). A key issue is the revival of populist parties in rich countries where democracy is well established.

Inglehart and Norris (2016) explore two leading explanations. First, there is the widely-held view that economic insecurity has caused the rise of populism. According to this view, deep structural transformations of the last fifty years have created economic uncertainty and social malaise, especially amongst the economic losers of these transformations. The second view focuses on cultural backlash. In addition to deep economic changes, the last fifty years have seen profound social transformation; the introduction of new values in the society has caused a reaction in sectors of the population which felt threatened. Using the European Social Survey, Inglehart and Norris (2016) find strong evidence in favour of the cultural backlash hypothesis. This finding suggests that the traditional left-right cleavage, on which politics was based before the 80 s, is being substituted by a new cleavage between traditional and progressive values in (post-modern) Western societies. Inglehart and Norris (2016) also

\footnotetext{
${ }^{3}$ Political scientists have worked extensively on populism. Even a simple review of the literature on populism in political science is well beyond the scope of this paper. We quote only few authors whose work is close to our approach.
} 
find evidence that the support for populist parties comes from small shop keepers and not from lowwage workers and that unemployment status and income are bad predictors of populist votes.

The view that in post-modern societies voting is more affected by cultural factors than by wealth or income is important for this paper. In fact, in a post-modern world, associations, which are part of the individual's cultural world, should play an increasing role in determining voting intentions.

\section{Are voters irrational?}

Economists have found it particularly difficult to explain the success of populist parties because support for populism challenges the usual assumption in political economy that individuals act (and vote) following their own interests. Economists have long-maintained that populists in power implement policies that in the long-run damage the whole economy and, particularly, those groups that populists are supposed to favour (Dornbusch and Edwards, 1992; Houle and Kenny, 2016). Why do people vote for populist movements that ultimately go against their own interests? If populism leads to bad economic consequences (as economists assume), why do people support populist parties? This seems to violate the principle of rationality.

Economists provided different answers to this question. Dornbusch and Edwards (1992) argue that (most) voters are short-sighted and often misinformed; this explains why they supported political movements in Latin America that promised wealth for everybody and ignored budget constraints. Caplan (2007) provides evidence that American voters do not behave rationally, at least in the economic sphere. Acemoğlu et al. (2013) argue that populist policies are a signalling device by honest politicians directed to voters who have imperfect information about the politicians. Populist politicians choose 'extremist' policies to signal that they are not beholden to special interest. Di Tella and Rotemberg (2017) add voters' distaste for 'betrayal' to a standard model and argue that voters prefer having incompetent leaders rather than feel betrayed. These explanations have merits, but also the big limit that they do not build on the insights of political science. Finally, Rodrik (2017) argues that populism is a rational response to the shocks caused by globalization.

The views in this debate on the rationality of the voter span a wide range. However, all have the implicit assumption that the individual chooses (rationally or irrationally). Our paper innovates in this respect and shows that associations play a key role in explaining the populist votes. 


\section{Social Capital and populism}

The role of social capital has been recognized in economics for a long time (for instance, Making Democracy Work or Bowling Alone by Putnam.) Building on Tocqueville's intuition, Putnam argues that social capital, which was key in building American society, has been declining since the 1960s. According to him, the decline in social capital has increased unhappiness and political apathy. Crucially, low level of social capital also decreases confidence in government and lowers frequency in voting and participating in political activity. In his original work, he did not deal directly with populism but all these correlates of social capital are often associated with populism. Satyanath et al. (2018) argue instead that there is a "dark side" of social capital, documenting that social capital aided the rise of the Nazi movement that ultimately destroyed Germany's first democracy. ${ }^{4}$

This paper also builds on this strand of the literature in linking social capital as measured by membership in association with populism. ${ }^{5}$

\section{Economic crises and populism}

The global financial crisis (or Great Recession) in 2008/9 and the Euro crisis in 2012 have had unprecedented economic consequences; did the economic crises also cause political crises? After all, political crises and the ascent of Nazism followed the economic crisis in the thirties. Political scientists and economists give different answers to this question.

Rovira Kaltwasser, and Zanotti (2016) state that "in contrast to alarmist reports in the media claiming that the Great Recession is triggering the rise of anger, extremism and protest across Europe, most comparative (party) politics literature on the Great Recession tend to argue that so far the political consequences of the crisis have been limited." The extended state of welfare is credited for preventing a different outcome than in the 30s. Moreover, the evidence points that the recession itself has not caused a large increase of votes for the French Front Nationale (Mayer, 2014). The discontent caused

\footnotetext{
${ }^{4}$ Even de Tocqueville (1835) warned about the dark side of civil capital: "the liberty of association is only a source of advantage and prosperity to some nations, it may be perverted ... and ... changed into a cause of destruction."

${ }^{5}$ Putnam distinguishes between two types of social capital - bonding and bridging capital. Bonding capital is among similar people with similar race, age, level of education. Bridging capital is among other people who do not necessarily share the same characteristics but share some value. In our empirical analysis we cannot distinguish between the two types of capital. In any case, Putnam himself argues that bonding and bridging capitals are correlated.
} 
by the economic crisis seems to have been channelled through retrospective voting (i.e. voters punish incumbents in government irrespective of their ideology). According to this view, the rise of populism after the Great Recession is the continuation of a pre-existing trend of punishment of the ruling class via voting for parties with mostly inexperienced politicians presenting themselves as antiestablishment.

Economists hold the opposite view that the economic crises had profound political effects and, in particular, are fostering populism. Guiso et al. (2017), Algan et al. (2017), the EEAG report (2017), Dustmann et al. (2017) argue that the crises and the attendant economic insecurity undermined trust in institutions, in particular, European institutions. Similarly, Funke et. al. (2017) find that voters flock to extremist parties, located at both ends of the political spectrum, after financial crises.

Contributing to this literature, our paper finds that the crises had indeed an effect on the voting preferences, but this was intermediated by associations. Results somewhat similar to ours were obtained by Coffé et al. (2007) in their analysis of the electoral success of the Vlaams Blok in the 2004 Flemish regional elections. They found the right-wing populists to be particularly successful in municipalities with a small network of social organizations.

\section{Data}

This section starts with a brief account of the sources from which data were obtained followed by a first look at basic trends and descriptive statistics.

\section{Sources}

Our dataset is at an individual level and is drawn primarily from the European Social Survey (ESS). The ESS maps the attitudes, beliefs, and behaviour patterns to socio-economic and demographic variables. The surveys take place every two years, though not all countries and individuals participate in all the waves. Therefore, we have a repeated cross-section rather than a panel. The data measure voting patterns at the individual level. The ESS asks individuals whether they voted in the last Parliamentary election and if they did, which party they voted for. The sample covers 17 European countries over the period 2002-16 (Table A1).

We also use data on voting patterns in Latin America from the Latinobarometro. The Latinobarometro is also an individual level survey similar to ESS, though with very limited information, and reduced coverage, relative to the ESS. The Latinobarometro also measures voting 
behaviour but asks a different question: if individuals are asked to vote the following Sunday for Parliamentary or Presidential election, which party would they vote for. The data for Latin America is very limited, covering 17 countries from 1996-2008 with many gaps (Table A1). Given the limited coverage, we exercise caution in interpreting the results for Latin America and treat them as only suggestive evidence.

To identify populist parties in Europe and Latin America, we follow the recent literature (Inglehart and Norris 2016). Inglehart and Norris classify populist parties based on the 2014 Chapel Hill Expert Survey (CHES). The CHES uses expert ratings on position of parties on a range of characteristics such as support for traditional values, liberal lifestyles, and multiculturalism, including economic characteristics such as state of the economy, and market deregulation. Inglehart and Norris classify a party as populist if it scores more than 80 points on a standardized 100-point scale built using thirteen selected indicators contained in the CHES. This definition of populist party is time-invariant. We follow the same methodology to classify populist parties in Europe and Latin America. Based on this methodology, we define 28 parties in Europe and 22 parties in Latin America as populist.

A key variable in our analysis is membership of civil society associations. We construct association membership rates for Europe using the ESS. Membership of civil society associations is elicited from a question on personal involvement in actions "trying to improve things or help prevent things from going wrong". We consider members of civil society associations those stating not to have "contacted a politician" or "worked in a political party", or "belonging to any particular religion or denomination" but to have "worked in another organization or association during the last 12 months". More specifically, an individual is defined to be a member of a civil society association, if during the last 12 months he has worked in an organization or association trying to improve things or help prevent things from going wrong in her country. In some specifications we also use a measure of self-reported trade union membership, though we argue later in the paper that this measure is more likely to be contaminated by endogeneity concerns than membership of civil societies. We define an individual to be a member of a trade union if he/she is currently "a member of a trade union or similar organization".

The Latinobarometro dataset also has information on whether an individual is a member of any association, including trade union, though the variable is not available for most years. Moreover, the exact definition of association membership in the Latinobarometro varies from year to year. In the 
2008 survey, for example, the definition includes membership in trade or labor unions as well as groups or associations related to "politics", “students", "religious", “culture”, "sport", or "ecology".

We use several other socio-economic variables such as age, gender, income, and education. Details of all the variables used in the empirical analysis is provided in Table A2. Table A3 provides descriptive statistics for the variables used in the analysis.

\section{A first look at the data}

Before going into the econometric analysis, we analyse the evolution of our key variables over time and analyse simple correlations. In Europe, there is no clear trend in populist vote intention between 2002 and 2016. Close to 10 percent of the population said they would vote for populist parties in 2002; the figure increased to close to 15 percent by mid-2000, before beginning to decline again more recently. This is consistent with the fact that, despite popular perception, there is not an overwhelming trend in favour of populism in Europe (Mudde and Rovira-Kaltwasser, 2017.) For Latin America, we find a clear break in the trend towards populism. Populism was flat till mid-2000s but has increased sharply since then. The rise of populism in Europe till mid 2000s has coincided with a rather constant level of civil association membership whilst union membership has been on a declining trend. In general union membership rates display a much higher time variation than membership in civil society associations.

Only for selected countries in Europe, such as Turkey, populist in power were associated with declining membership of associations. In the case of Latin America, on average, association membership rates have decreased in parallel with a rise in populism. In Brazil and Argentina, the years when populists were in power were also years when membership of associations declined.

How does membership of civil society association interact with political preferences for populist parties? Do populism and decline in, broadly speaking, association membership rates (including unions) go hand in hand, or are they driven by a third factor? We analyse these issues more rigorously in the next section using a novel dataset on voting patterns and association membership rates.

\section{Empirical Specification}

We set out the empirical analysis by first estimating baseline logit and probit models, followed by an extended specification based on the Heckman model.

CInternational Monetary Fund. Not for Redistribution 


\section{Baseline specification}

We estimate the drivers of populist vote using linear probability, logit, and probit models. The estimating equation is specified as follows:

$$
\begin{aligned}
& D_{i, c, t}=\operatorname{aAssoc}_{i, c, t}+\beta \text { Sufficient Income } \text { I }, c, t+\gamma \text { Difficult Income }_{i, c, t}+\delta \text { Gender }_{i, c, t}+ \\
& \zeta \text { young }_{i, c, t}+\eta \text { old }_{i, c, t}+\theta \text { secondary education }_{i, c, t}+\kappa \text { tertiary education }_{i, c, t}+s_{c}+v_{t}+ \\
& s_{c} * v_{t}+\varepsilon_{i, t},
\end{aligned}
$$

where $D_{i, c, t}$ is a dummy that takes a value of 1 if individual $i$ in country $c$ at time $t$ votes for a populist party. $A s \operatorname{soc}_{i, c, t}$ takes a value of 1 if the individual is a member of a civil society association. The

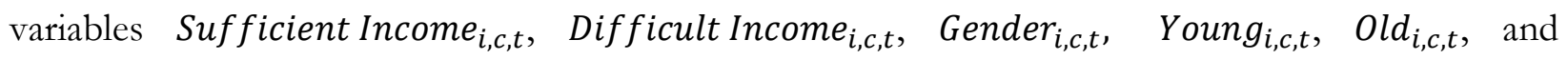
Secondary Education $_{i, c, t}$ Tertiary Education $_{i, c, t}$ are indicators which take the value of 1 respectively if the individual reports to have sufficient income, to be in a difficult income situation, to be female, to be younger than 30, to be 65 or older, have secondary education with 12 years of completed schooling, and to have tertiary education with 16 or more years of completed schooling. ${ }^{6}$

The variables $s_{c}$ and $v_{t}$ denote country and time fixed effects respectively. Country fixed effects control for all time-invariant country characteristics that may affect individuals' preferences to vote for populist or non-populist parties, e.g. historical background, culture, or legal system. Time effects capture any time trends in voting behaviour that are common across countries, e.g. the global financial crisis, or a common rise in populism across the globe.

Importantly, the interactions $s_{c} * v_{t}$, capture any observed and unobserved country and time varying characteristics, e.g. country-specific trends in the supply of populist parties and in the evolution of their platforms. In fact, this paper is the first one in the literature to control for any unobserved country-specific time trends in populism. In addition, the terms $s_{C} * v_{t}$ also control for any countryspecific time trends in association membership rates. The standard errors for the estimated coefficients in all regressions are clustered at the country-level.

\section{Empirical Results}

\footnotetext{
${ }^{6}$ The main findings in the paper are robust to including age and age-squared instead of indicators for young and old.
} 
This section first reports results using a large voting dataset from 17 European countries followed by results from a smaller yet quite representative dataset from 17 Latin American countries.

\section{Baseline Evidence from European voting data}

We first show results for drivers of voting for populists using the ESS. Our dataset includes observations from 17 European countries with eight waves.

Table 1-2 shows the results from estimating Equation (1) by OLS and Probit respectively. Column 1 pools data from all available years from 2002-2016. Our key variable of interest is membership in a civil association. The estimated coefficient for this variable is negative in Column 1 of Tables 1-2 i.e. individuals who belong to associations are less likely to vote for populist parties. The result holds also across all waves in Tables 1 and 2, with the exception of 2004 in Table 1.

The coefficient on civil association is about 3 percent. This is a large number considering that the average vote share for populist parties is between 10 and 15 percent in most countries. In other words, membership of civil society reduces the vote for populist party by 20 to 30 per cent.

In addition to membership in a civil organization, being female and having attained tertiary education are consistently negative and highly significant i.e. females and highly educated are significantly less likely to vote for populist parties. Self-reporting insufficient income or income difficulties are significant sporadically but, in general, consistent with economic explanations of populism: selfreporting having sufficient income is negatively correlated with voting for populist parties while reporting income difficulties is positively associated with voting for populist parties.

\section{Effect of the European crises}

Europe experienced the global financial crisis in 2008-9 and the Southern part of the Eurozone experienced another severe recession in 2012. Did the crises change the effect of associations on voting pattern?

Columns 2 and 3 in Tables 1 and 2 report the results when we split the samples between 2002-10, and 2012-16. These two sub-periods are chosen also in light of the retrospective nature of the question on individuals votes. Columns 4-11 show the results for specific years. The coefficient on civil association membership is negative and statistically significant for every year (with the exception of 2004 for OLS

in Table 1) but becomes even more negative after the global financial crisis. Note also that the 
coefficient of the variable for (self-reported) insufficient income is negative and significant after the global financial crisis; and its magnitude increased 2-3 times in the post crisis period.

What can explain the increasing negative correlation between civil association membership and populist vote? One potential explanation is that before the crisis party discipline was strong, and ideological vote was important. Post crisis, notably with the collapse of social-democratic parties across Europe, individual beliefs became unhinged. With more unhinged beliefs, people felt more open to vote for new parties. Civil associations, on the other hand, provided ideological anchors and voice mechanisms alternative to voting for outsiders. Therefore, individuals who belonged to these associations voted less for populist parties. This explanation is also consistent with the view that social capital represented by civil associations membership has a long-term effect which manifests itself in moment of crises. Another complementary explanation is that economic crises have a big role in the system of beliefs on the role of the state (Giuliano and Spilimbergo, 2013). People, mostly young ones, demand more from the state but, at the same time, are more sceptical about the state. This unanswered demand is fulfilled by civil society associations and less by populist voting. Last but not least, the crisis had an impact on the supply of populist parties, making the vote more responsive to civil association membership.

\section{Extended specification correcting for potential sample selection bias}

OLS and Probit regressions have the potential problem of self-selection given voters may decide not to vote. Indeed, individuals make two decisions: (i) whether to vote in an election, and (ii) conditional on voting, which party to vote for, whether to vote for a populist party or not. This issue has been recognized in the literature, e.g. in Guiso et. al. 2017, and has been addressed through a two-step Heckman model, to account for the bias that may result from the fact that party choice apply only to voters who turnout to vote.

Following the literature, we estimate a two-step Heckman model. In the first stage, we estimate the probability of participation. In the second stage, we estimate the probability of voting for a populist party. For identification, we need to introduce at least one variable which affects the probability of voting but does not have a direct effect on the choice of party. As instrument we use proxies for lack of awareness about public choice issues.

We assume that lack of awareness affects voter turnout by increasing the cost of acquiring information about political platforms and candidates but does not directly impact choice of political party. We use 
several proxies for lack of awareness. The proxies are measured by the number of "don't know" or "no answer" to questions relating to "anything about politics": (i) TV watching, news/politics/current affairs on average weekday, (ii) how interested in politics, (iii) able to take active role in political group, (iv) confident in own ability to participate in politics, (v) easy to take part in politics, (vi) placement on left right scale, (vii) state of education in country nowadays, (viii) state of health services in country nowadays.

Table 3 shows the results from estimating Equation (1) by the 2-step Heckman model respectively. Table $3 \mathrm{a}$ reports the estimates from the second stage of Heckman, while Table $3 \mathrm{~b}$ reports the first stage estimates. The first stage reported in Table $3 \mathrm{~b}$ shows the coefficient on our proxies for lack of awareness is strongly negative and statistically significant ${ }^{7}$. We find strong evidence that individuals who are less aware are less likely to participate in elections, suggesting that lack of awareness is a strong instrument. Overall, the results from estimating the 2-step Heckman model support the main finding in Tables 1 and 2, and establish more conclusively that populism is negatively associated with civil society membership in Europe. Women, high income, highly educated, and older individuals, are less likely to vote for populist parties. The evidence is consistent with the hypothesis that voting for populist parties is less likely among people who are likely to be more economically secure.

The rest of the findings are broadly consistent with the literature. Income affects participation positively. High income individuals are more likely to vote, but less likely to vote populist. Low income individuals are less likely to participate, but have an insignificant effect on voting populist, relative to other individuals.

Controlling for other variables, women participate as much as men but, conditional on voting, they are less likely to vote for populist parties. The coefficient on women is consistently (and significantly) negative. The negative relationship between women and far-right populist parties in Europe has been long noted (see Mudde, 2007, for a summary). In the past, authors have argued that women may be discouraged by the fact that far right European parties have conservative values on civil rights, which may be not appealing to many women. More recently, Mudde (2007) has proposed an alternative explanation: women tend to vote for conservative parties but dislike extremist parties that are stigmatized as outsiders.

\footnotetext{
${ }^{7}$ While awareness is not significant when the dependent variable is vote for populist parties.
} 
Age affects participation positively, but, conditional on voting, it has an opposite effect on populist vote. Education is considered in the literature to be a proxy for the ability to gauge long term costs of current policies and is hypothesized to be negatively associated with populist vote. Our results support the significance of education; however, we find interesting variation across different categories of education. Individuals with tertiary education are more likely to participate in elections, but significantly less likely to vote for populist parties. Individuals with secondary education are also more likely to participate in elections relative to those who are not, but they are not significantly less likely to vote populist, unlike the tertiary educated. Therefore, while our results support the importance of education in determining populist voting patterns, we find that it is only the highly educated who are less likely to vote for populist parties.

\section{Robustness tests}

In this section, we conduct robustness checks to analyse whether the coefficient on membership in civil associations is robust to alternative specifications, explanatory variables, and instruments. Table 4 presents the first set of robustness tests. Panel A estimates a logit specification. Panel B includes only a subset of selection variables for the first stage equation in the Heckman procedure. In particular, it excludes (i) TV watching, news/politics/current affairs on average weekday, (ii) how interested in politics, (iii) able to take active role in political group, from the set of selection variables listed above, in order to explore whether the results are driven by these variables.

Another potential concern relates to omitted variables that could co-determine jointly the voting behaviour in favour of populist parties and the decision to join an association. Panels $C$ and $D$ include a number of additional controls proposed in Guiso et. al. (2017.) These include indicators for risk aversion, trust in parties and institutions, watching television, watching politics news and programs, the unemployment spell over the last 5 years, exposure to globalization, preference for lower immigration, perception of negative effect of immigrants, and right-wing ideology.

The main finding that membership of civil associations is negatively associated with voting for populist parties remains remarkably robust to different specifications, smaller set of selection variables, as well as additional controls. We do not introduce additional controls in the main specifications in Tables 1 3 to avoid issues of multicollinearity between the controls, and the Heckman 2-step estimates do not converge with the large set of additional controls.

CInternational Monetary Fund. Not for Redistribution 


\section{Including Trade Unions Membership}

Trade unions are a form of association and have traditionally played a big role in Europe. Do trade unions play the same role as other associations in diminishing the propensity for populist votes? ${ }^{8}$

In our dataset, the average trade union and association membership rates in the sample are similar, at 27 percent and 22 percent respectively (Table A4). But the trends in the two variables are also quite different. As shown in Figure 1, while trade union membership rates show a steady decline since 2002, membership of civil society associations, on average, remained relatively stable.

As a first pass, we do replicate the specification of Table 1 (OLS), Table 2 (Probit), and Table 3 (Heckman) but changing the definition of the key variable of interest. In Table 5 Panel A it is belonging to a civil association or to a trade union. The results are not as strong as in the regressions using only membership in civil society as explanatory variable (as in Tables 1 through 4). The OLS results are significant only after the crisis; the results with Probit and Heckman are more consistent across the time periods.

One possible concern is reverse causality or omitted variables. Given that membership in trade unions is more likely to be endogenous than civil society membership at these frequencies, we use an instrumental variables strategy specifically to address this concern. We use as an instrument the sectoral trade union density in another country for the same sector in which the ESS individual works. We choose the United Kingdom, because it is a country where there is no extended coverage of bargaining (or where "excess coverage" is low), and therefore trade union membership rates are an appropriate measure of the strength of collective workers' organizations. We assume that the sectoral trade union membership rates in the United Kingdom are exogenous to populist votes in other countries in our sample, which we believe is a reasonable assumption. To implement this strategy, we drop the United Kingdom from our regressions. The results are shown in Panel B in Table 5. The estimated coefficients on association or trade union membership remain negative and statistically significant in the instrumental variable estimations.

\section{Focusing on trade union membership}

In order to focus exclusively on the role of the trade unions, we replicate the same specification with only membership in trade union as explanatory variable (Table 6.) The results show that membership

\footnotetext{
${ }^{8}$ Note that the role of trade unions with respect with populism is ambiguous. For instance, in Argentina trade unions played a key role supporting Perón.
} 
in trade unions has little significant effect on the propensity to vote for populist parties except in the 2014 wave. This confirms that trade unions, despite being a form of association, are quite different from other associations. This is also confirmed from a historical point of view. In Argentina, trade unions played a big role during the Perón period in consolidating a populist regime. Instead of being a barrier to populism, trade unions did in fact become a transmission belt of populism.

\section{Role of the Trade Unions vs. Civil Associations}

Membership in trade unions and membership in associations are likely to be correlated. Indeed, the correlation coefficient between the two variables in our sample is positive and significant $(0.25$ and significant at 1 percent level). To disentangle the effects of these two variables we run our basic specification using the two variables (membership in trade unions and membership in civil associations.) The results are reported in Table 7, which follows the same structure as Table 6. The results show that membership in civil associations drives the results while membership in trade unions becomes insignificant in most of the cases

\section{Are the results sensitive to the exclusion of any specific country?}

To test the results from any specific country we replicate the Heckman specifications excluding one country at the time. The coefficients on associations are reported in Table 8. All coefficients remain highly significant in every year and excluding one country at the time.

We also run regressions on a subset of countries that are present in all waves of the survey. Our key results are, once more, unaffected ${ }^{9}$.

\section{Are the effects of association membership heterogeneous? Age and education}

In this sub-section, we analyse if the negative association between populist vote and association membership is driven by particular groups of individuals. Specifically, we analyse whether the effects are different across different age and education groups. We estimate the relationship between populist vote and civil association membership separately for three different age groups - young, middle-aged, and old. The results shown in Panel A of Table 9 show that populism and civil association membership do not depend on any specific age group. The negative correlation between populism and belonging

\footnotetext{
${ }^{9}$ Results are available upon request from the authors.
} 
to civil association, however, weakens in 2016 among the young, possibly indicating the importance of new social media, as collective voice mechanisms, for younger generations.

Panel A of Table 9 shows the results for three different education groups-less than secondary (i.e. less than 12 years of schooling), secondary to tertiary (between 12 and 16 years of schooling), and greater than tertiary (more than 16 years of schooling). Again, the negative correlation between belonging to civil association and populism is not driven by any education group.

\section{Evidence from Latin American voting data}

Next, we show results on drivers of voting for populism for Latin America, the continent with the longest history of populist parties in power. Another reason to analyse the Latin American case is that in these countries voting is compulsory (see Figure 2), making the issue of sample selection into voting less relevant than in Europe.

As noted above, the data for Latin America has very limited coverage, with much fewer observations compared to Europe. In addition, the data covers only the period from 1996 to 2008, with many gaps. Therefore, we cannot evaluate how the association between trade union membership and populist vote changed since the global fiscal crisis. Therefore, these results should be interpreted as being only suggestive, and should be taken with caution.

Table 9 presents the probit estimates of the drivers of populism for Latin America. The specification is identical to that for Europe. All regressions include indicators of income, age, gender, and education, and control for country* time fixed effects. All standard errors are clustered at the country level.

The results, however, are qualitatively similar to what we found for Europe. Populist vote and trade union membership go hand in hand in the earlier part of the sample, but move in opposite direction since 2007. The estimated coefficient on trade union membership is positive and statistically significant for the sample period from 1996-2005, but turn negative and significant during 2007-2008. In other words, we observe qualitatively similar patterns between Europe and Latin America, albeit with different samples and databases.

Note that under the Latin American voting dataset we do not perform the robustness test by replacing the logit and probit models with the Heckman specification due to lack of data on instruments. 


\section{Populists in Power}

Do populists in power foster or discourage membership in trade unions or associations? This section takes up this issue using a novel database on populists in power. ${ }^{10}$ The data on trade union density at the country-year level is taken from Visser (2016). The data refer to only "trade union density", defined as net trade union membership as a proportion of wage earners in employment; unlike the section above, we do not have information on broader association membership rate at the country-level.

We control for a possible feedback effect from populism to trade union membership by estimating the following simple regression: ${ }^{11}$

(2) Union $_{c, t}=a D_{\text {populist }, c, t}+s_{c}+v_{t}+X_{c, t}+\varepsilon_{c, t}$,

where Union $_{c, t}$ is the trade union density in country $c$ at time $t . D_{\text {populist }, c, t}$ is a dummy variable that takes a value of 1 , if the party in power in country $c$ at time $t$ is a populist party. We use the first difference of union densities to filter out any trends in trade union membership rates. ${ }^{12} S_{c}$ denotes country fixed effects, and controls for any country-specific trends in populism or changes in market structure affecting union power. $v_{t}$ denotes time fixed effects, and controls for any global shocks that affect all countries e.g. global trends in populism, or in changes in trade union density. $X_{c, t}$ includes indicators of economic crises, taken from Laeven and Valencia (2013), and take a value of 1 if there is a crisis (e.g. banking or sovereign debt) in country $c$ in year $t$. Note that we measure feedback effect from populism to trade union membership using aggregate data at the country-year level. Therefore, it is different from, and not comparable to specification (1), where we explored the drivers of individual voting patterns, and its association with the likelihood of individuals to join trade unions. Our sample includes 24 countries across Europe and Latin America, and covers the period 1990-2013 for which data are available.

The results from estimating Equation (2) are shown in Table 10. The estimated coefficient on trade union density is negative and statistically distinguishable from zero at conventional levels. The

\footnotetext{
10 The database was kindly shared by Kirk Hawkins. See Allred, Nathaniel, Kirk A. Hawkins, and Saskia P. Ruth. 2015. The data are created based on a textual analysis of four speeches for each leader-term (campaign, international, ribbon cutting, famous) and the scale runs from 0 to 2, higher numbers meaning a stronger populist discourse in the speech. Therefore, it is a measure of how populist the leader is for whatever he/she is in power.

${ }^{11}$ For trade union density we use the "Database on Institutional Characteristics of Trade Unions, Wage Setting, State Intervention and Social Pacts, ICTWSS” (available at http:/ /www.edac.eu/indicators desc.cfm?v id=215)

12 The findings are qualitatively similar even if we use the trade union density in levels, and introduce country fixed effects, which implicitly transforms the dependent and explanatory variables into the difference from the mean.
} 
estimates suggest that controlling for country-specific and time trends, as well as indicators of economic hardship, trade union densities are estimated to be lower by about 3 percentage points in countries where populists are in power, compared to those where populists are not in power. Overall, we do find some evidence that populists in power are associated with lower trade union densities. This result has to be taken with caution because the relationship of unions with populism, especially in Latin America, is ambiguous as mentioned before.

\section{Conclusions}

Researchers have focused on the many reasons behind populism, including cultural backlash, economic uncertainty, and lack of trust. But no previous study has focused on the role of civil society. Civil society has long been recognized as a key defence of liberal democracy as Alexis de Tocqueville wrote almost two centuries ago. At the same time, populists, who do not see a role for civil society, may pragmatically use associations as transmission belts, as the historical experience in Latin America may indicate. Thus, one can find arguments for civil society being a protective shield against populism or a vehicle of the populist ideology and the role of civil society in the rise of populism is an empirical matter However, empirical tests have been lacking. This paper fills this gap.

This paper is innovative also because it encompasses both Europe and Latin America, in contrast from previous studies. This is important because Latin America has a longstanding experience with populist parties in power, and the literature in political science has recognized that all populisms have important traits in common despite the obvious differences due to the different geographical areas and right or left orientation. Our results show remarkable similarities in Latin America and Europe, an indication that the issue highlighted in the paper is important in understanding populism in general. This paper has also shown that unions in Europe (different from other associations) have a weak negative association with populism.

Finally, this paper also sheds new light on the role of the global financial crisis in the political process. The global financial crisis has not simply caused a populist wave. Rather, it may have changed (and enhanced) the role of civil society. In a world where political systems, institutions, and ideologies have been put into question and even discredited where social democracy in Europe almost disappeared, civil society assumes a new role.

But this paper also opens important questions for future research. First, why the role of civil associations as a vaccine against the populist vote was less important before the global financial crisis? 
Second, what are the specific mechanisms through which belonging to a civil association lowers the populist vote? Is it because associations provide alternative information or because they offer an ideological anchor? Is it because they promote social responsibility beyond onesself? Is it because they offer voice mechanisms alternative to exit-punishment of incumbents? Is it because civil society associations are identity providers moderating the impact of migration on the identity of local communities? Third, are all associations equivalent or are some associations more effective? Fourth, do associations have a similar impact on all members of society or is belonging to an association more relevant for some groups? Future research, possibly benefitting from data also covering the refugee crisis, should further investigate these issues. 
Table 1. OLS Estimates of Drivers of Populist Party Vote

\begin{tabular}{|c|c|c|c|c|c|c|c|c|c|c|c|}
\hline & [1] & {$[2]$} & [3] & [4] & [5] & {$[6]$} & [7] & [8] & [9] & [10] & [11] \\
\hline & All & Pre-2010 & Post-2012 & 2002 & 2004 & 2006 & 2008 & 2010 & 2012 & 2014 & 2016 \\
\hline \multirow[t]{2}{*}{ Civil Associations } & $-2.53 * * *$ & $-2.06 * *$ & $-3.24 * * *$ & $-2.02 *$ & -1.99 & $-2.30 * *$ & $-1.70 * *$ & $-2.22 * * *$ & $-2.71 * * *$ & $-3.51 * * *$ & $-3.51 * * *$ \\
\hline & [0.59] & {$[0.82]$} & {$[0.68]$} & [1.14] & [1.18] & [0.88] & {$[0.74]$} & {$[0.73]$} & [0.83] & {$[0.73]$} & [0.85] \\
\hline \multirow[t]{2}{*}{ Income Sufficient } & $-1.07 * * *$ & $-0.64 * *$ & $-1.72 * * *$ & $-0.97 * * *$ & -0.58 & -0.36 & 0.14 & $-1.56 * *$ & -1.11 & $-2.12 * * *$ & $-1.78^{*}$ \\
\hline & {$[0.35]$} & [0.29] & {$[0.50]$} & {$[0.31]$} & {$[0.50]$} & {$[0.60]$} & {$[0.50]$} & [0.59] & {$[0.65]$} & {$[0.57]$} & [0.88] \\
\hline \multirow[t]{2}{*}{ Income Difficult } & $1.70 * *$ & 0.93 & $3.03 * *$ & 0.18 & -0.34 & 1.66 & 1.90 & 1.15 & 2.52 & $2.06^{*}$ & $5.61 * *$ \\
\hline & {$[0.80]$} & {$[0.64]$} & {$[1.21]$} & {$[0.55]$} & [0.69] & {$[1.25]$} & [1.59] & {$[0.73]$} & [1.48] & [1.02] & [1.86] \\
\hline \multirow[t]{2}{*}{ Female } & $-2.45 * * *$ & $-2.05^{* * *}$ & $-3.06 * * *$ & $-1.58 * *$ & $-2.28 * *$ & $-2.27 * * *$ & $-1.71 * *$ & $-2.40 * * *$ & $-2.75 * * *$ & $-2.85 * * *$ & $-3.72 * * *$ \\
\hline & {$[0.51]$} & {$[0.56]$} & {$[0.76]$} & {$[0.70]$} & {$[0.85]$} & {$[0.67]$} & {$[0.65]$} & {$[0.56]$} & {$[0.84]$} & {$[0.78]$} & [0.95] \\
\hline \multirow[t]{2}{*}{ Young } & 0.52 & 0.89 & -0.14 & 0.95 & 0.42 & 1.21 & 0.63 & 1.21 & 1.29 & -0.31 & -1.82 \\
\hline & {$[0.66]$} & {$[0.68]$} & [0.83] & {$[0.57]$} & {$[0.42]$} & [1.79] & [1.13] & [1.13] & {$[0.85]$} & [1.16] & {$[1.62]$} \\
\hline \multirow[t]{2}{*}{ Old } & -0.92 & -0.15 & $-2.04 * *$ & 0.74 & -0.25 & -0.81 & 0.12 & -0.50 & -1.38 & $-2.53 * *$ & $-2.28 * *$ \\
\hline & {$[0.70]$} & [0.63] & {$[0.88]$} & {$[0.45]$} & {$[0.61]$} & [0.79] & [1.17] & [1.06] & [1.11] & {$[1.15]$} & [0.99] \\
\hline \multirow[t]{2}{*}{ Secondary Education } & 0.50 & 0.89 & -0.20 & $1.32 *$ & 0.63 & 0.72 & 1.81 & 0.07 & -0.79 & 0.31 & 0.19 \\
\hline & [0.78] & {$[0.74]$} & {$[1.03]$} & {$[0.70]$} & {$[0.74]$} & [0.99] & [1.33] & [1.10] & {$[1.00]$} & {$[1.56]$} & {$[1.48]$} \\
\hline \multirow[t]{2}{*}{ Tertiary Education } & $-4.89 * * *$ & $-3.60 * * *$ & $-6.88 * * *$ & $-1.64 *$ & $-3.42 * *$ & $-4.31 * *$ & $-2.78^{*}$ & $-5.49 * *$ & $-6.86 * * *$ & $-6.75 * * *$ & $-6.95 * * *$ \\
\hline & [1.14] & {$[1.22]$} & {$[1.44]$} & {$[0.85]$} & {$[1.51]$} & {$[1.78]$} & {$[1.56]$} & [1.99] & [1.74] & [1.85] & [1.47] \\
\hline Country*Year FE & $\mathrm{Y}$ & Y & Y & Y & Y & $\mathrm{Y}$ & $\mathrm{Y}$ & Y & Y & $\mathrm{Y}$ & Y \\
\hline Obs. & 135980 & 84595 & 51385 & 17484 & 15466 & 16832 & 17140 & 17673 & 19198 & 17633 & 14554 \\
\hline R-Squared & 0.22 & 0.22 & 0.21 & 0.09 & 0.12 & 0.21 & 0.21 & 0.30 & 0.27 & 0.20 & 0.13 \\
\hline
\end{tabular}

Notes. The dependent variable in all regressions is a dummy=1 if the individual votes for a populist party, and 0 otherwise. "Civil Associations" takes a value of 1 if the individual is a member of a civil society association, and 0 otherwise. "Income sufficient" takes a value of 1 if the individual responds that income is sufficient, and 0 otherwise. "Income difficult" takes a value of 1 if the individual responds to be in a difficult income situation, and 0 otherwise. "Young" takes a value of 1 if the individual is less than 30 years of age, and 0 otherwise. "Old" takes a value of 1 if the individual is 65 years or older, and 0 otherwise. "Secondary education" takes a value of 1 if the individual has attained secondary education, with 12 or more years of completed schooling, and 0 otherwise. "Tertiary education" takes a value of 1 if the individual has attained tertiary education, with 16 or more years of completed schooling, and 0 otherwise. The standard errors in all regressions are clustered at the country-level. ***, **, and * denote statistical significance at 1,5 , and 10 percent levels, respectively. 
Table 2. Probit Estimates of Drivers of Populist Party Vote

\begin{tabular}{|c|c|c|c|c|c|c|c|c|c|c|c|}
\hline & [1] & [2] & [3] & {$[4]$} & [5] & {$[6]$} & [7] & [8] & [9] & [10] & [11] \\
\hline & All & Pre-2010 & Post-2012 & 2002 & 2004 & 2006 & 2008 & 2010 & 2012 & 2014 & 2016 \\
\hline \multirow[t]{2}{*}{ Civil Associations } & $-3.29 * * *$ & $-2.95 * * *$ & $-3.72 * * *$ & $-2.91 * * *$ & $-2.62 * *$ & $-3.69 * * *$ & $-2.53^{* * *}$ & $-2.73^{* * *}$ & $-3.12^{* * *}$ & $-3.83^{* * *}$ & $-4.24 * * *$ \\
\hline & {$[0.47]$} & {$[0.70]$} & {$[0.55]$} & {$[0.97]$} & {$[1.24]$} & [0.87] & {$[0.86]$} & {$[0.76]$} & {$[0.79]$} & {$[0.58]$} & {$[0.68]$} \\
\hline \multirow[t]{2}{*}{ Income Sufficient } & $-1.57^{* * *}$ & $-1.12^{* *}$ & $-2.13 * * *$ & $-1.42 * * *$ & -0.74 & -0.96 & -0.33 & $-2.05^{* *}$ & $-1.65 * *$ & $-2.33 * * *$ & $-2.30^{* *}$ \\
\hline & {$[0.44]$} & {$[0.44]$} & [0.43] & [0.47] & {$[0.67]$} & {$[0.83]$} & {$[0.80]$} & {$[0.84]$} & {$[0.67]$} & {$[0.54]$} & {$[0.95]$} \\
\hline \multirow[t]{2}{*}{ Income Difficult } & $1.63^{* * *}$ & 0.92 & $2.60^{* * *}$ & 0.23 & -0.15 & 1.09 & 1.65 & $1.26^{*}$ & $2.22^{* *}$ & $1.76^{* *}$ & $4.41^{* * *}$ \\
\hline & {$[0.61]$} & {$[0.60]$} & {$[0.71]$} & {$[0.90]$} & {$[1.15]$} & {$[0.75]$} & [1.30] & {$[0.69]$} & {$[0.98]$} & {$[0.87]$} & {$[0.68]$} \\
\hline \multirow[t]{2}{*}{ Female } & $-2.97^{* * *}$ & $-2.76 * * *$ & $-3.22 * * *$ & $-2.48 * * *$ & $-3.37 * * *$ & $-2.63 * * *$ & $-2.23^{* * *}$ & $-3.15^{* * *}$ & $-3.10^{* * *}$ & $-2.85 * * *$ & $-3.86^{* * *}$ \\
\hline & {$[0.61]$} & {$[0.58]$} & [0.74] & [0.51] & [0.69] & {$[0.75]$} & {$[0.84]$} & {$[0.70]$} & [0.92] & {$[0.63]$} & {$[1.01]$} \\
\hline \multirow[t]{2}{*}{ Young } & 0.77 & $1.33^{* *}$ & -0.07 & $1.61^{* * *}$ & 0.62 & 1.64 & 1.06 & 1.47 & $1.21 *$ & -0.43 & -1.32 \\
\hline & {$[0.56]$} & {$[0.66]$} & {$[0.69]$} & {$[0.50]$} & {$[0.67]$} & [1.62] & [1.11] & [1.05] & {$[0.71]$} & {$[1.16]$} & {$[1.17]$} \\
\hline \multirow[t]{2}{*}{ Old } & -1.14 & -0.36 & $-2.08^{* *}$ & 0.88 & -0.37 & -1.01 & -0.05 & -0.88 & -1.54 & $-2.39 * *$ & $-2.27^{* *}$ \\
\hline & {$[0.77]$} & {$[0.72]$} & {$[0.85]$} & {$[0.59]$} & {$[0.86]$} & {$[0.72]$} & [1.28] & {$[1.22]$} & {$[1.21]$} & {$[1.05]$} & {$[0.93]$} \\
\hline \multirow[t]{2}{*}{ Secondary Education } & -0.17 & 0.09 & -0.45 & 0.83 & -0.58 & -0.20 & 1.36 & -0.76 & -1.13 & -0.02 & -0.07 \\
\hline & {$[0.77]$} & {$[0.90]$} & {$[0.93]$} & {$[1.06]$} & {$[1.62]$} & [0.99] & {$[1.88]$} & {$[1.28]$} & {$[0.78]$} & [1.44] & {$[1.04]$} \\
\hline \multirow[t]{2}{*}{ Tertiary Education } & $-7.08^{* * *}$ & $-6.13 * * *$ & $-8.22^{* * *}$ & $-4.23 * * *$ & $-6.42 * * *$ & $-6.50 * * *$ & $-4.89 * *$ & $-8.09 * * *$ & $-8.62 * * *$ & $-7.65 * * *$ & $-8.40^{* * *}$ \\
\hline & {$[1.01]$} & [1.17] & [1.24] & [1.41] & [1.06] & [1.61] & {$[2.29]$} & [1.86] & [1.15] & [1.67] & {$[1.45]$} \\
\hline Country*Year FE & Y & Y & Y & $\mathrm{Y}$ & Y & $\mathrm{Y}$ & Y & Y & Y & Y & Y \\
\hline Obs. & 112907 & 64625 & 48282 & 10914 & 10908 & 15318 & 13311 & 14174 & 16850 & 17633 & 13799 \\
\hline
\end{tabular}

Notes. The dependent variable in all regressions is a dummy $=1$ if the individual votes for a populist party, and 0 otherwise. "Civil Associations" takes a value of 1 if the individual is a member of a civil society association, and 0 otherwise. "Income sufficient" takes a value of 1 if the individual responds that income is sufficient, and 0 otherwise. "Income difficult" takes a value of 1 if the individual responds to be in a difficult income situation, and 0 otherwise. "Young" takes a value of 1 if the individual is less than 30 years of age, and 0 otherwise. "Old" takes a value of 1 if the individual is 65 years or older, and 0 otherwise. "Secondary education" takes a value of 1 if the individual has attained secondary education, with 12 or more years of completed schooling, and 0 otherwise. "Tertiary education" takes a value of 1 if the individual has attained tertiary education, with 16 or more years of completed schooling. The coefficient estimates in all the specifications indicate marginal effects. The standard errors in all regressions are clustered at the country-level. $* * *, * *$, and $*$ denote statistical significance at 1,5, and 10 percent levels, respectively. Number of observations are lower relative to Table 1 since for some country in some year, there is no populist party to vote, and those need to be excluded from the Probit estimation. 
Table 3a. Drivers of Populist Party Vote. Heckman 2nd Stage Estimates

\begin{tabular}{|c|c|c|c|c|c|c|c|c|c|c|c|}
\hline & [1] & {$[2]$} & [3] & [4] & {$[5]$} & {$[6]$} & [7] & [8] & [9] & [10] & [11] \\
\hline & All & Pre-2010 & Post-2012 & 2002 & 2004 & 2006 & 2008 & 2010 & 2012 & 2014 & 2016 \\
\hline \multirow[t]{2}{*}{ Civil Associations } & $-2.74 * * *$ & $-2.42 * * *$ & $-3.22 * * *$ & $-2.03 * * *$ & $-1.97 * *$ & $-3.57 * * *$ & $-2.14 * * *$ & $-2.31 * * *$ & $-2.56 * * *$ & $-3.38 * * *$ & $-3.85 * * *$ \\
\hline & {$[0.36]$} & {$[0.55]$} & {$[0.42]$} & {$[0.60]$} & {$[0.86]$} & [0.83] & {$[0.73]$} & {$[0.66]$} & {$[0.64]$} & {$[0.49]$} & {$[0.56]$} \\
\hline \multirow[t]{2}{*}{ Income Sufficient } & $-1.24 * * *$ & $-1.01 * * *$ & $-1.53 * * *$ & $-1.07 * * *$ & -0.61 & -0.91 & -0.52 & $-1.91 * * *$ & $-1.15^{*}$ & $-1.59 * *$ & $-1.86^{*}$ \\
\hline & [0.39] & {$[0.36]$} & {$[0.48]$} & {$[0.41]$} & {$[0.48]$} & {$[0.72]$} & {$[0.81]$} & {$[0.66]$} & {$[0.61]$} & {$[0.63]$} & [0.97] \\
\hline \multirow[t]{2}{*}{ Income Difficult } & $1.24 * *$ & $0.90^{*}$ & $1.68^{*}$ & 0.31 & 0.01 & 1.00 & 1.64 & $1.30 * * *$ & 1.36 & 0.73 & $3.57 * * *$ \\
\hline & {$[0.55]$} & {$[0.50]$} & {$[0.88]$} & {$[0.57]$} & {$[0.77]$} & {$[0.67]$} & {$[1.22]$} & {$[0.50]$} & [0.99] & [0.89] & [0.95] \\
\hline \multirow[t]{2}{*}{ Female } & $-2.49 * * *$ & $-2.25 * * *$ & $-2.89 * * *$ & $-1.73 * * *$ & $-2.50 * * *$ & $-2.55^{* * *}$ & $-1.86 * * *$ & $-2.68 * * *$ & $-2.65 * * *$ & $-2.60 * * *$ & $-3.58 * * *$ \\
\hline & {$[0.48]$} & {$[0.46]$} & {$[0.61]$} & {$[0.28]$} & {$[0.49]$} & {$[0.73]$} & {$[0.67]$} & {$[0.63]$} & {$[0.76]$} & {$[0.55]$} & {$[0.85]$} \\
\hline \multirow[t]{2}{*}{ Young } & 0.41 & $1.40^{* *}$ & $-1.04 * *$ & $1.44^{* *}$ & 0.71 & 1.49 & 1.58 & 1.71 & 0.14 & -1.80 & $-1.81 * *$ \\
\hline & {$[0.44]$} & [0.59] & {$[0.48]$} & {$[0.56]$} & {$[0.67]$} & {$[1.58]$} & [1.09] & {$[1.07]$} & {$[0.63]$} & [1.10] & {$[0.90]$} \\
\hline \multirow[t]{2}{*}{ Old } & -0.85 & -0.42 & $-1.25 * *$ & 0.53 & -0.38 & -0.93 & -0.28 & -1.00 & -0.80 & -1.32 & $-1.68 * * *$ \\
\hline & {$[0.61]$} & {$[0.63]$} & [0.62] & {$[0.42]$} & {$[0.61]$} & {$[0.78]$} & {$[1.18]$} & [1.15] & {$[0.94]$} & {$[0.83]$} & {$[0.65]$} \\
\hline \multirow[t]{2}{*}{ Secondary Education } & -0.05 & -0.04 & 0.10 & 0.44 & -0.52 & -0.16 & 0.97 & -0.85 & -0.51 & 0.58 & 0.33 \\
\hline & {$[0.64]$} & {$[0.77]$} & {$[0.79]$} & {$[0.78]$} & [1.17] & {$[1.07]$} & {$[1.56]$} & {$[1.06]$} & {$[0.66]$} & [1.27] & {$[0.89]$} \\
\hline \multirow[t]{2}{*}{ Tertiary Education } & $-5.68 * * *$ & $-5.32 * * *$ & $-6.05 * * *$ & $-3.25 * * *$ & $-5.03 * * *$ & $-6.20 * * *$ & $-4.70 * * *$ & $-7.32 * * *$ & $-6.17 * * *$ & $-5.33 * * *$ & $-6.84 * * *$ \\
\hline & {$[0.76]$} & {$[0.90]$} & {$[1.20]$} & {$[0.79]$} & {$[0.83]$} & {$[1.90]$} & {$[1.75]$} & [1.67] & [1.23] & {$[1.72]$} & [1.19] \\
\hline Country*Year FE & $\mathrm{Y}$ & Y & $Y$ & $Y$ & $Y$ & $Y$ & $Y$ & $Y$ & $Y$ & $Y$ & Y \\
\hline Obs. & 178289 & 110472 & 67817 & 22139 & 20795 & 21663 & 22325 & 23550 & 25461 & 23625 & 18731 \\
\hline \multicolumn{12}{|c|}{$\begin{array}{l}\text { Notes. This table shows the estimates from the second stage of the Heckman } 2 \text {-step process. The dependent variable in all regressions is a } \\
\text { dummy } 1 \text { if the individual votes for a populist party, and } 0 \text { otherwise. "Civil Associations" takes a value of } 1 \text { if the individual is a member of a civil } \\
\text { society association, and } 0 \text { otherwise. "Income sufficient" takes a value of } 1 \text { if the individual responds that income is sufficient, and } 0 \text { otherwise. } \\
\text { "Income difficult" takes a value of } 1 \text { if the individual responds to be in a difficult income situation, and } 0 \text { otherwise. "Young" takes a value of } 1 \text { if the } \\
\text { individual is less than } 30 \text { years of age, and } 0 \text { otherwise. "Old" takes a value of } 1 \text { if the individual is } 65 \text { years or older, and } 0 \text { otherwise. "Secondary } \\
\text { education" takes a value of } 1 \text { if the individual has attained secondary education, with } 12 \text { or more years of completed schooling, and } 0 \text { otherwise. } \\
\text { "Tertiary education" takes a value of } 1 \text { if the individual has attained tertiary education, with } 16 \text { or more years of completed schooling. The identifying } \\
\text { variables used in the first stage regression includes proxies for lack of political awareness - as captured by "don't know" in response to any of the } \\
\text { questions relating to "anything about politics": (i) TV watching, news/politics/current affairs on average weekday, (ii) How interested in politics, (iii) } \\
\text { Able to take active role in political group, (iv) Confident in own ability to participate in politics, (v) Easy to take part in politics, (vi) Placement on left } \\
\text { right scale, (vii) State of education in country nowadays, (viii) State of health services in country nowadays. See Table } 3 \mathrm{~b} \text { for results from the first } \\
\text { stage regressions. The coefficient estimates in all the specifications indicate marginal effects. The standard errors in all regressions are clustered at the } \\
\text { country-level. ***, **, and * denote statistical significance at } 1,5 \text {, and } 10 \text { percent levels, respectively. }\end{array}$} \\
\hline
\end{tabular}


Table 3b. Drivers of Populist Party Vote. Heckman 1st Stage Estimates

\begin{tabular}{|c|c|c|c|c|c|c|c|c|c|c|c|}
\hline & [1] & [2] & [3] & [4] & [5] & [6] & [7] & [8] & [9] & {$[10]$} & [11] \\
\hline & All & Pre-2010 & Post-2012 & 2002 & 2004 & 2006 & 2008 & 2010 & 2012 & 2014 & 2016 \\
\hline \multicolumn{12}{|c|}{ Number of "don't know" response to "anything } \\
\hline about politics" & $\begin{array}{c}-0.52 * * * \\
{[0.03]}\end{array}$ & $\begin{array}{c}-0.54^{* * *} \\
{[0.04]}\end{array}$ & $\begin{array}{c}-0.49 * * * \\
{[0.02]}\end{array}$ & $\begin{array}{c}-0.50^{* * *} \\
{[0.04]}\end{array}$ & $\begin{array}{c}-0.59 * * * \\
{[0.04]}\end{array}$ & $\begin{array}{c}-0.53^{* * *} \\
{[0.06]}\end{array}$ & $\begin{array}{c}-0.56^{* * *} \\
{[0.07]}\end{array}$ & $\begin{array}{c}-0.53 * * * \\
{[0.05]}\end{array}$ & $\begin{array}{c}-0.55^{* * *} \\
{[0.07]}\end{array}$ & $\begin{array}{c}-0.44^{* * *} \\
{[0.04]}\end{array}$ & $\begin{array}{c}-0.52^{* * *} \\
{[0.04]}\end{array}$ \\
\hline Income Sufficient & $\begin{array}{c}0.20^{* * *} \\
{[0.03]}\end{array}$ & $\begin{array}{c}0.19^{* * *} \\
{[0.03]}\end{array}$ & $\begin{array}{c}0.22^{* * *} \\
{[0.02]}\end{array}$ & $\begin{array}{c}0.18^{* * *} \\
{[0.05]}\end{array}$ & $\begin{array}{c}0.13^{* * *} \\
{[0.04]}\end{array}$ & $\begin{array}{c}0.15^{* * *} \\
{[0.03]}\end{array}$ & $\begin{array}{c}0.25 * * * \\
{[0.03]}\end{array}$ & $\begin{array}{c}0.23^{* * *} \\
{[0.05]}\end{array}$ & $\begin{array}{c}0.19^{* * *} \\
{[0.04]}\end{array}$ & $\begin{array}{c}0.23^{* * *} \\
{[0.02]}\end{array}$ & $\begin{array}{c}0.24^{* * *} \\
{[0.03]}\end{array}$ \\
\hline Income Difficult & $\begin{array}{c}-0.23^{* * *} \\
{[0.03]}\end{array}$ & $\begin{array}{c}-0.23^{* * *} \\
{[0.04]}\end{array}$ & $\begin{array}{c}-0.24^{* * *} \\
{[0.03]}\end{array}$ & $\begin{array}{c}-0.25^{* * *} \\
{[0.02]}\end{array}$ & $\begin{array}{c}-0.27^{* * *} \\
{[0.03]}\end{array}$ & $\begin{array}{c}-0.25^{* * *} \\
{[0.06]}\end{array}$ & $\begin{array}{c}-0.19 * * * \\
{[0.06]}\end{array}$ & $\begin{array}{c}-0.22^{* * *} \\
{[0.05]}\end{array}$ & $\begin{array}{c}-0.22^{* * *} \\
{[0.04]}\end{array}$ & $\begin{array}{c}-0.23^{* * *} \\
{[0.04]}\end{array}$ & $\begin{array}{c}-0.27^{* * *} \\
{[0.03]}\end{array}$ \\
\hline Female & $\begin{array}{c}-0.02 \\
{[0.02]}\end{array}$ & $\begin{array}{c}0.00 \\
{[0.02]}\end{array}$ & $\begin{array}{c}-0.06^{* * *} \\
{[0.01]}\end{array}$ & $\begin{array}{c}0.01 \\
{[0.04]}\end{array}$ & $\begin{array}{l}-0.02 \\
{[0.03]}\end{array}$ & $\begin{array}{l}-0.02 \\
{[0.03]}\end{array}$ & $\begin{array}{c}0.00 \\
{[0.02]}\end{array}$ & $\begin{array}{c}0.05 \\
{[0.03]}\end{array}$ & $\begin{array}{c}-0.06^{* * *} \\
{[0.02]}\end{array}$ & $\begin{array}{c}-0.04 * * \\
{[0.02]}\end{array}$ & $\begin{array}{c}-0.07^{* *} \\
{[0.03]}\end{array}$ \\
\hline Young & $\begin{array}{c}-0.53^{* * *} \\
{[0.03]}\end{array}$ & $\begin{array}{c}-0.55^{* * *} \\
{[0.04]}\end{array}$ & $\begin{array}{c}-0.50^{* * *} \\
{[0.04]}\end{array}$ & $\begin{array}{c}-0.59^{* * *} \\
{[0.06]}\end{array}$ & $\begin{array}{c}-0.57^{* * *} \\
{[0.07]}\end{array}$ & $\begin{array}{c}-0.52^{* * *} \\
{[0.05]}\end{array}$ & $\begin{array}{c}-0.56^{* * *} \\
{[0.04]}\end{array}$ & $\begin{array}{c}-0.48^{* * *} \\
{[0.05]}\end{array}$ & $\begin{array}{c}-0.50^{* * *} \\
{[0.05]}\end{array}$ & $\begin{array}{c}-0.52^{* * *} \\
{[0.05]}\end{array}$ & $\begin{array}{c}-0.49^{* * *} \\
{[0.06]}\end{array}$ \\
\hline Old & $\begin{array}{c}0.33^{* * *} \\
{[0.04]}\end{array}$ & $\begin{array}{c}0.30^{* * *} \\
{[0.04]}\end{array}$ & $\begin{array}{c}0.38^{* * *} \\
{[0.04]}\end{array}$ & $\begin{array}{c}0.22^{* * *} \\
{[0.05]}\end{array}$ & $\begin{array}{c}0.29 * * * \\
{[0.05]}\end{array}$ & $\begin{array}{c}0.33^{* * *} \\
{[0.05]}\end{array}$ & $\begin{array}{c}0.28^{* * *} \\
{[0.06]}\end{array}$ & $\begin{array}{c}0.35^{* * *} \\
{[0.05]}\end{array}$ & $\begin{array}{c}0.36 * * * \\
{[0.05]}\end{array}$ & $\begin{array}{c}0.38^{* * *} \\
{[0.05]}\end{array}$ & $\begin{array}{c}0.40^{* * *} \\
{[0.05]}\end{array}$ \\
\hline Secondary Education & $\begin{array}{c}0.20^{* * *} \\
{[0.06]}\end{array}$ & $\begin{array}{c}0.17^{* * *} \\
{[0.06]}\end{array}$ & $\begin{array}{c}0.25^{* * *} \\
{[0.05]}\end{array}$ & $\begin{array}{c}0.20^{* * *} \\
{[0.07]}\end{array}$ & $\begin{array}{l}0.17^{*} \\
{[0.09]}\end{array}$ & $\begin{array}{c}0.17^{* *} \\
{[0.07]}\end{array}$ & $\begin{array}{c}0.09 \\
{[0.07]}\end{array}$ & $\begin{array}{c}0.21^{* * *} \\
{[0.07]}\end{array}$ & $\begin{array}{c}0.26 * * * \\
{[0.06]}\end{array}$ & $\begin{array}{c}0.21^{* * *} \\
{[0.06]}\end{array}$ & $\begin{array}{c}0.29 * * * \\
{[0.04]}\end{array}$ \\
\hline Tertiary Education & $\begin{array}{c}0.56^{* * *} \\
{[0.07]}\end{array}$ & $\begin{array}{c}0.52^{* * *} \\
{[0.08]}\end{array}$ & $\begin{array}{c}0.63^{* * * *} \\
{[0.06]}\end{array}$ & $\begin{array}{c}0.55^{* * *} \\
{[0.09]}\end{array}$ & $\begin{array}{c}0.58^{* * *} \\
{[0.11]}\end{array}$ & $\begin{array}{c}0.50^{* * *} \\
{[0.09]}\end{array}$ & $\begin{array}{c}0.45^{* * * *} \\
{[0.09]}\end{array}$ & $\begin{array}{c}0.55 * * * \\
{[0.09]}\end{array}$ & $\begin{array}{c}0.61^{* * *} \\
{[0.07]}\end{array}$ & $\begin{array}{c}0.58^{* * *} \\
{[0.08]}\end{array}$ & $\begin{array}{c}0.71^{* * *} \\
{[0.07]}\end{array}$ \\
\hline Country*Year FE & Y & Y & Y & Y & Y & Y & Y & Y & Y & $\mathrm{Y}$ & $\mathrm{Y}$ \\
\hline Obs. & 178289 & 110472 & 67817 & 22139 & 20795 & 21663 & 22325 & 23550 & 25461 & 23625 & 18731 \\
\hline
\end{tabular}

Notes. This table shows the estimates from the first stage of the Heckman 2-step process. The dependent variable in all regressions is a dummy $=1$ if the individual votes, and 0 otherwise. The identifying variables used in the first stage regression includes proxies for lack of political awareness - as captured by the total number of "don't know" in response to any of the questions relating to "anything about politics": (i) TV watching, news/politics/current affairs on average weekday, (ii) How interested in politics, (iii) Able to take active role in political group, (iv) Confident in own ability to participate in politics, (v) Easy to take part in politics, (vi) Placement on left right scale, (vii) State of education in country nowadays, (viii) State of health services in country nowadays. "Income sufficient" takes a value of 1 if the individual responds that is income is sufficient, and 0 otherwise. "Income difficult" takes a value of 1 if the individual responds to be in a difficult income situation, and 0 otherwise. "Young" takes a value of 1 if the individual is less than 30 years of age, and 0 otherwise. "Old" takes a value of 1 if the individual is 65 years or older, and 0 otherwise. "Secondary education" takes a value of 1 , if the individual has attained secondary education, with 12 or more years of completed schooling, and 0 otherwise. "Tertiary education" takes a value of 1 if the individual has attained tertiary education, with 16 or more years of completed schooling. The standard errors in all regressions are clustered at the country-level. ***, **, and * denote statistical significance at 1,5, and 10 percent levels, respectively. 
Table 4. Drivers of Populist Party Vote: Robustness

\begin{tabular}{|c|c|c|c|}
\hline & $\begin{array}{l}\text { [1] } \\
\text { All }\end{array}$ & $\begin{array}{c}{[2]} \\
\text { Pre-2010 }\end{array}$ & $\begin{array}{c}{[3]} \\
\text { Post-2012 }\end{array}$ \\
\hline \multicolumn{4}{|l|}{ Panel A. Logit } \\
\hline Civil Associations & $\begin{array}{c}-3.44 * * * \\
{[0.50]}\end{array}$ & $\begin{array}{c}-3.07 * * * \\
{[0.73]}\end{array}$ & $\begin{array}{c}-3.91 * * * \\
{[0.61]}\end{array}$ \\
\hline Observations & 112907 & 64625 & 48282 \\
\hline \multicolumn{4}{|c|}{$\begin{array}{l}\text { Panel B. Heckman II: Selection variable. "Don't know" to (i) Confident in own ability to participate in politics, (ii) Easy to take } \\
\text { part in politics, (iii) Placement on left right scale, (iv) State of education in country nowadays, (v) State of health services in } \\
\text { country nowadays }\end{array}$} \\
\hline Civil Associations & $\begin{array}{c}-2.77^{* * *} \\
{[0.37]}\end{array}$ & $\begin{array}{c}-2.44^{* * *} \\
{[0.55]}\end{array}$ & $\begin{array}{c}-3.24^{* * *} \\
{[0.43]}\end{array}$ \\
\hline Observations & 178153 & 110385 & 67768 \\
\hline \multicolumn{4}{|c|}{ Panel C. OLS: Additional controls } \\
\hline Civil Associations & $\begin{array}{c}-1.55 * * * \\
{[0.48]}\end{array}$ & $\begin{array}{l}-1.22^{*} \\
{[0.57]}\end{array}$ & $\begin{array}{c}-1.99 * * \\
{[0.73]}\end{array}$ \\
\hline Observations & 115168 & 69727 & 45441 \\
\hline \multicolumn{4}{|c|}{ Panel D. Probit: Additional controls } \\
\hline Civil Associations & $\begin{array}{c}-2.20 * * * \\
{[0.42]}\end{array}$ & $\begin{array}{c}-1.82 * * * \\
{[0.47]}\end{array}$ & $\begin{array}{c}-2.61^{* * *} \\
{[0.66]}\end{array}$ \\
\hline Observations & 97074 & 54333 & 42741 \\
\hline \multicolumn{4}{|c|}{$\begin{array}{l}\text { Note. This table reports coefficient estimates for key variables only. All regressions include the controls in Table } 1 \text {. The additional } \\
\text { controls in Panels C and D are those in Guiso et al. (2017), and include indicators for risk aversion, watching television, watching } \\
\text { politics news and programs, unemployment spell over the last } 5 \text { years, exposure to globalization, preference for lower immigration, } \\
\text { perception of negative effect of immigrants, trust in parties and institutions, and right-wing ideology. Heckman } 2 \text {-step estimates are } \\
\text { not reported with additional controls, as the estimates fail to converge with the large set of additional controls. The coefficient } \\
\text { estimates in the Probit and Heckman specifications indicate marginal effects. The standard errors in all regressions are clustered at the } \\
\text { country-level. ***,**, and } * \text { denote statistical significance at } 1,5 \text {, and } 10 \text { percent levels, respectively. }\end{array}$} \\
\hline
\end{tabular}


Table 5. Populist Vote and Civil Associations / Trade Union Membership

\begin{tabular}{|c|c|c|c|c|c|c|c|c|c|c|c|}
\hline & $\begin{array}{l}{[1]} \\
\text { All }\end{array}$ & $\begin{array}{c}{[2]} \\
\text { Pre-2010 }\end{array}$ & $\begin{array}{c}{[3]} \\
\text { Post2012 }\end{array}$ & $\begin{array}{c}{[4]} \\
2002\end{array}$ & $\begin{array}{c}{[5]} \\
2004\end{array}$ & $\begin{array}{c}{[6]} \\
2006\end{array}$ & $\begin{array}{c}{[7]} \\
2008\end{array}$ & $\begin{array}{c}{[8]} \\
2010\end{array}$ & $\begin{array}{c}{[9]} \\
2012\end{array}$ & $\begin{array}{l}{[10]} \\
2014\end{array}$ & $\begin{array}{c}{[11]} \\
2016\end{array}$ \\
\hline \multicolumn{12}{|c|}{ Panel A. No IV } \\
\hline \multicolumn{12}{|c|}{ OLS } \\
\hline Civil Associations & $-1.88 * *$ & -1.47 & $-2.51 * * *$ & -1.57 & -1.14 & $-1.96 *$ & -1.31 & -1.24 & $-1.74^{*}$ & $-3.26 * * *$ & $-2.51 * *$ \\
\hline or Trade Union & {$[0.71]$} & {$[0.85]$} & [0.61] & [1.09] & [1.13] & [0.92] & {$[0.78]$} & {$[0.72]$} & {$[0.84]$} & [0.73] & [0.83] \\
\hline Observations & 135705 & 84426 & 51279 & 17455 & 15434 & 16800 & 17116 & 17621 & 19156 & 17577 & 14546 \\
\hline \multicolumn{12}{|c|}{ Probit } \\
\hline Civil Associations & $-2.20 * * *$ & $-1.89 * *$ & $-2.57 * * *$ & $-2.25 * *$ & -1.48 & $-2.53 * * *$ & $-1.70 * *$ & $-1.28 *$ & $-1.86^{* *}$ & $-3.19 * * *$ & $-2.58 * * *$ \\
\hline or Trade Union & [0.69] & {$[0.82]$} & {$[0.61]$} & {$[1.06]$} & [1.17] & [0.81] & {$[0.86]$} & {$[0.73]$} & [0.93] & [0.59] & {$[0.84]$} \\
\hline Observations & 112691 & 64501 & 48190 & 10892 & 10889 & 15286 & 13294 & 14140 & 16822 & 17577 & 13791 \\
\hline \multicolumn{12}{|c|}{ Heckman } \\
\hline \multicolumn{12}{|l|}{ Heckman 2nd } \\
\hline Civil Associations & $-1.83 * * *$ & $-1.55^{* *}$ & $-2.21 * * *$ & $-1.57^{* *}$ & -1.11 & $-2.44 * * *$ & $-1.46^{*}$ & $-1.08 *$ & $-1.50 * *$ & $-2.79 * * *$ & $-2.35 * * *$ \\
\hline or Trade Union & [0.57] & {$[0.67]$} & [0.49] & {$[0.74]$} & {$[0.81]$} & {$[0.78]$} & {$[0.75]$} & {$[0.62]$} & {$[0.76]$} & [0.51] & {$[0.74]$} \\
\hline \multicolumn{12}{|l|}{ Heckman 1st } \\
\hline \multirow[t]{2}{*}{ "Don't know" } & $-0.53 * * *$ & $-0.55 * * *$ & $-0.50 * * *$ & $-0.51 * * *$ & $-0.59 * * *$ & $-0.53 * * *$ & $-0.56 * * *$ & $-0.54 * * *$ & $-0.55^{* * *}$ & $-0.45 * * *$ & $-0.53 * * *$ \\
\hline & [0.03] & [0.04] & [0.02] & {$[0.04]$} & [0.04] & [0.06] & [0.07] & {$[0.05]$} & [0.07] & [0.04] & [0.04] \\
\hline Observations & 178014 & 110303 & 67711 & 22110 & 20763 & 21631 & 22301 & 23498 & 25419 & 23569 & 18723 \\
\hline \multicolumn{12}{|c|}{ Panel B. Using sectoral union membership rates in UK as IV } \\
\hline \multicolumn{12}{|c|}{ OLS } \\
\hline \multicolumn{12}{|l|}{ 2nd stage - } \\
\hline Civil Associations & $-8.82 *$ & -6.21 & $-13.36 * * *$ & -1.51 & -7.28 & $-9.90 *$ & -6.35 & -6.47 & -8.04 & $-14.33^{* *}$ & $-19.12 * * *$ \\
\hline or Trade Union & {$[0.05]$} & [5.73] & [4.16] & [4.92] & [7.41] & {$[5.56]$} & [8.00] & [8.08] & [6.58] & [5.98] & [7.38] \\
\hline Observations & 116540 & 71391 & 45149 & 13948 & 12838 & 14453 & 14765 & 15387 & 16841 & 15548 & 12760 \\
\hline \multicolumn{12}{|c|}{ Probit } \\
\hline \multicolumn{12}{|l|}{ 2nd stage - } \\
\hline Civil Associations & $-10.21 * *$ & -7.32 & $-15.10 * * *$ & -1.87 & -7.54 & $-11.15^{*}$ & -7.69 & -8.62 & -8.54 & $-16.39 * *$ & $-22.58 * * *$ \\
\hline or Trade Union & [5.10] & [6.57] & [4.26] & [7.23] & [7.32] & [5.87] & [9.72] & {$[8.51]$} & {$[6.54]$} & [6.63] & [6.23] \\
\hline Observations & 102907 & 59406 & 43501 & 10026 & 10340 & 13019 & 12478 & 13543 & 15922 & 15548 & 12031 \\
\hline \multicolumn{12}{|c|}{ Heckman } \\
\hline \multicolumn{12}{|c|}{ 2nd stage - Heckman 2nd } \\
\hline Civil Associations & $-9.08 * *$ & -6.45 & $-13.00 * * *$ & -1.43 & -6.90 & $-10.11^{*}$ & -6.94 & -8.20 & -7.31 & $-14.02 * *$ & $-19.89 * * *$ \\
\hline or Trade Union & [4.59] & {$[5.74]$} & [3.95] & [5.52] & {$[6.66]$} & {$[5.62]$} & [8.33] & [7.95] & {$[5.73]$} & [5.92] & [5.72] \\
\hline \multicolumn{12}{|c|}{ 2nd stage - Heckman 1st } \\
\hline "Don't know" & $-0.55 * * *$ & $-0.58 * * *$ & $-0.51 * * *$ & $-0.55 * * *$ & $-0.63 * * *$ & $-0.55 * * *$ & $-0.59 * * *$ & $-0.57 * * *$ & $-0.57 * * *$ & $-0.45 * * *$ & $-0.56 * * *$ \\
\hline & {$[0.04]$} & {$[0.04]$} & [0.03] & {$[0.05]$} & {$[0.05]$} & [0.07] & [0.09] & [0.05] & [0.08] & {$[0.04]$} & [0.03] \\
\hline Observations & 154367 & 94370 & 59997 & 18083 & 17658 & 18664 & 19316 & 20649 & 22510 & 20957 & 16530 \\
\hline \multicolumn{12}{|c|}{ IV 1st - Stage } \\
\hline UK UM & $\begin{array}{c}0.31 * * * \\
{[0.01]}\end{array}$ & $\begin{array}{c}0.34 * * * \\
{[0.01]}\end{array}$ & $\begin{array}{c}0.27^{* * *} \\
{[0.01]}\end{array}$ & $\begin{array}{c}0.38^{* * *} \\
{[0.02]}\end{array}$ & $\begin{array}{c}0.38^{* * *} \\
{[0.02]}\end{array}$ & $\begin{array}{c}0.32 * * * \\
{[0.02]}\end{array}$ & $\begin{array}{c}0.31 * * * \\
{[0.02]}\end{array}$ & $\begin{array}{c}0.29 * * * \\
{[0.02]}\end{array}$ & $\begin{array}{c}0.25 * * * \\
{[0.02]}\end{array}$ & $\begin{array}{c}0.26^{* * *} \\
{[0.02]}\end{array}$ & $\begin{array}{c}0.29 * * * \\
{[0.03]}\end{array}$ \\
\hline
\end{tabular}

Note. This table reports coefficient estimates for key variables only. All regressions include the controls in Table 1. The coefficient estimates in Probit and Heckman specifications indicate marginal effects. ${ }^{* * *},{ }^{* *}$, and ${ }^{*}$ denote statistical significance at 1,5 , and 10 percent levels, respectively. 
Table 6. Populist Vote and Trade Union Membership

\begin{tabular}{|c|c|c|c|c|c|c|c|c|c|c|c|}
\hline & [1] & {$[2]$} & [3] & {$[4]$} & {$[5]$} & [6] & [7] & {$[8]$} & [9] & [10] & {$[11]$} \\
\hline & All & Pre-2010 & Post2012 & 2002 & 2004 & 2006 & 2008 & 2010 & 2012 & 2014 & 2016 \\
\hline \multicolumn{12}{|c|}{ Panel A. No IV } \\
\hline \multicolumn{12}{|c|}{ OLS } \\
\hline \multirow[t]{2}{*}{ Trade Union } & -1.06 & -0.93 & $-1.25^{*}$ & -1.06 & -0.99 & -0.98 & -0.88 & -0.63 & -0.83 & $-1.83 * * *$ & -1.08 \\
\hline & {$[0.75]$} & {$[0.87]$} & [0.67] & [0.91] & {$[1.26]$} & {$[0.92]$} & [1.16] & {$[0.78]$} & [0.95] & [0.60] & [1.07] \\
\hline Observations & 135864 & 84534 & 51330 & 17475 & 15451 & 16827 & 17128 & 17653 & 19184 & 17600 & 14546 \\
\hline \multicolumn{12}{|c|}{ Probit } \\
\hline \multirow[t]{2}{*}{ Trade Union } & -1.21 & -1.21 & -1.14 & -1.66 & -1.42 & -1.24 & -1.12 & -0.50 & -0.88 & $-1.63 * * *$ & -0.79 \\
\hline & {$[0.82]$} & {$[0.94]$} & {$[0.77]$} & {$[1.06]$} & [1.43] & {$[0.94]$} & [1.32] & {$[0.90]$} & [1.12] & [0.63] & [1.15] \\
\hline Observations & 112787 & 64556 & 48231 & 10904 & 10896 & 15313 & 13294 & 14149 & 16839 & 17600 & 13792 \\
\hline \multicolumn{12}{|c|}{ Heckman } \\
\hline \multicolumn{12}{|l|}{ Heckman 2nd } \\
\hline \multirow[t]{2}{*}{ Trade Union } & -1.00 & -0.99 & -0.95 & -1.15 & -1.06 & -1.19 & -0.96 & -0.43 & -0.69 & $-1.42 * *$ & -0.70 \\
\hline & [0.68] & [0.77] & {$[0.66]$} & [0.77] & [1.02] & [0.91] & [1.12] & {$[0.75]$} & [0.91] & [0.56] & [1.04] \\
\hline \multicolumn{12}{|l|}{ Heckman 1st } \\
\hline \multirow[t]{2}{*}{ "Don't know" } & $-0.53 * * *$ & $-0.54 * * *$ & $-0.50 * * *$ & $-0.50 * * *$ & $-0.59 * * *$ & $-0.53 * * *$ & $-0.56 * * *$ & $-0.54 * * *$ & $-0.55 * * *$ & $-0.45 * * *$ & $-0.53 * * *$ \\
\hline & [0.03] & [0.04] & [0.02] & {$[0.04]$} & [0.04] & {$[0.06]$} & [0.07] & [0.05] & [0.07] & [0.05] & [0.03] \\
\hline Observations & 178173 & 110411 & 67762 & 22130 & 20780 & 21658 & 22313 & 23530 & 25447 & 23592 & 18723 \\
\hline \multicolumn{12}{|c|}{ Panel B. Using sectoral union membership rates in UK as IV } \\
\hline \multicolumn{12}{|c|}{ OLS } \\
\hline \multicolumn{12}{|l|}{ 2nd stage - } \\
\hline \multirow[t]{2}{*}{ Trade Union } & $-7.71 *$ & -5.40 & $-11.75 * * *$ & -1.43 & -6.16 & $-7.59 *$ & -6.09 & -5.75 & -7.49 & $-12.43 * *$ & $-16.42 * *$ \\
\hline & [4.03] & [4.96] & [3.89] & [4.37] & [6.48] & [4.08] & [7.54] & [7.14] & [6.13] & {$[5.05]$} & [6.45] \\
\hline Observations & 116667 & 71475 & 45192 & 13966 & 12851 & 14470 & 14774 & 15414 & 16863 & 15569 & 12760 \\
\hline \multicolumn{12}{|c|}{ Probit } \\
\hline \multicolumn{12}{|l|}{ 2nd stage - } \\
\hline \multirow[t]{2}{*}{ Trade Union } & $-8.86 * *$ & -6.33 & $-13.12 * * *$ & -1.70 & -6.42 & $-8.63 * *$ & -7.64 & -7.41 & -7.74 & $-14.27^{* *}$ & $-19.08 * * *$ \\
\hline & [4.39] & [5.59] & [3.68] & [6.18] & [6.33] & [4.31] & [9.63] & [7.18] & [5.66] & [5.87] & [5.16] \\
\hline Observations & 102988 & 59453 & 43535 & 10037 & 10348 & 13036 & 12479 & 13553 & 15935 & 15569 & 12031 \\
\hline \multicolumn{12}{|c|}{ Heckman } \\
\hline \multicolumn{12}{|l|}{ Heckman 2nd } \\
\hline \multirow[t]{2}{*}{ Trade Union } & $-7.94 * *$ & -5.63 & $-11.41 * * *$ & -1.36 & -5.85 & $-7.75^{*}$ & -6.68 & -7.29 & -6.73 & $-12.20 * *$ & $-17.10 * * *$ \\
\hline & [3.98] & [4.92] & [3.45] & [4.89] & [0.0571] & [0.0410] & {$[0.0798]$} & [0.0693] & [0.0506] & [0.0524] & [0.0480] \\
\hline \multicolumn{12}{|l|}{ Heckman 1st } \\
\hline \multirow[t]{2}{*}{ “Don't know" } & $-0.55^{* * *}$ & $-0.52 * * *$ & $-0.51 * * *$ & $-0.54 * * *$ & $-0.62 * * *$ & $-0.55 * * *$ & $-0.59 * * *$ & $-0.56 * * *$ & $-0.57 * * *$ & $-0.45 * * *$ & $-0.56 * * *$ \\
\hline & [0.04] & [0.04] & [0.03] & [0.05] & [0.05] & [0.07] & [0.08] & [0.05] & [0.08] & [0.04] & [0.03] \\
\hline Observations & 154494 & 94454 & 60040 & 18101 & 17671 & 18681 & 19325 & 20676 & 22532 & 20978 & 16530 \\
\hline \multicolumn{12}{|c|}{ IV 1st - Stage } \\
\hline UK UM & $\begin{array}{c}0.36 * * * \\
{[0.01]}\end{array}$ & $\begin{array}{c}0.39 * * * \\
{[0.01]}\end{array}$ & $\begin{array}{c}0.31 * * * \\
{[0.01]}\end{array}$ & $\begin{array}{c}0.43^{* * *} \\
{[0.02]}\end{array}$ & $\begin{array}{c}0.44 * * * \\
{[0.02]}\end{array}$ & $\begin{array}{c}0.43 * * * \\
{[0.02]}\end{array}$ & $\begin{array}{c}0.33 * * * \\
{[0.02]}\end{array}$ & $\begin{array}{c}0.33^{* * *} \\
{[0.02]}\end{array}$ & $\begin{array}{c}0.29 * * * \\
{[0.02]}\end{array}$ & $\begin{array}{c}0.30 * * * \\
{[0.02]}\end{array}$ & $\begin{array}{c}0.34 * * * \\
{[0.02]}\end{array}$ \\
\hline
\end{tabular}

Note. This table reports coefficient estimates for key variables only. All regressions include the controls in Table 1. The coefficient estimates in Probit and Heckman specifications indicate marginal effects. ${ }^{* * *},{ }^{* *}$, and $*$ denote statistical significance at 1,5 , and 10 percent levels, respectively. 
Table 7. Populist Vote and Trade Union and Civil Associations Membership

\begin{tabular}{|c|c|c|c|c|c|c|c|c|c|c|c|}
\hline & $\begin{array}{l}{[1]} \\
\text { All }\end{array}$ & $\begin{array}{c}{[2]} \\
\text { Pre-2010 }\end{array}$ & $\begin{array}{c}{[3]} \\
\text { Post2012 }\end{array}$ & $\begin{array}{c}{[4]} \\
2002\end{array}$ & $\begin{array}{c}{[5]} \\
2004\end{array}$ & $\begin{array}{c}{[6]} \\
2006\end{array}$ & $\begin{array}{c}{[7]} \\
2008\end{array}$ & $\begin{array}{c}{[8]} \\
2010\end{array}$ & $\begin{array}{c}{[9]} \\
2012\end{array}$ & $\begin{array}{l}{[10]} \\
2014\end{array}$ & $\begin{array}{l}{[11]} \\
2016\end{array}$ \\
\hline \multicolumn{12}{|c|}{ Panel A. No IV } \\
\hline \multicolumn{12}{|c|}{ OLS } \\
\hline \multirow[t]{2}{*}{ Civil Associations } & $-2.49 * * *$ & $-2.02 * *$ & $-3.19 * * *$ & $-1.96 *$ & -1.92 & $-2.27 * *$ & $-1.68 * *$ & $-2.20 * * *$ & $-2.68 * * *$ & $-3.46 * * *$ & $-3.45 * * *$ \\
\hline & [0.56] & [0.79] & [0.68] & [1.10] & [1.15] & {$[0.84]$} & [0.73] & [0.72] & [0.83] & [0.73] & [0.84] \\
\hline \multirow[t]{2}{*}{ Trade Union } & -0.93 & -0.81 & -1.12 & -0.96 & -0.88 & -0.84 & -0.73 & -0.54 & -0.77 & $-1.71 * *$ & -0.86 \\
\hline & {$[0.72]$} & [0.83] & {$[0.65]$} & [0.87] & [1.23] & {$[0.88]$} & [1.14] & [0.79] & [0.93] & {$[0.58]$} & [1.05] \\
\hline Observations & 135623 & 84368 & 51255 & 17448 & 15417 & 16786 & 17106 & 17611 & 19144 & 17572 & 14539 \\
\hline \multicolumn{12}{|c|}{ Probit } \\
\hline \multirow[t]{2}{*}{ Civil Associations } & $-3.24 * * *$ & $-2.89 * * *$ & $-3.67 * * *$ & $-2.79 * * *$ & $-2.51 * *$ & $-3.65 * * *$ & $-2.51 * * *$ & $-2.72 * * *$ & $-3.08 * * *$ & $-3.79 * * *$ & $-4.18 * * *$ \\
\hline & [0.46] & [0.68] & [0.55] & [0.94] & [1.26] & [0.81] & [0.86] & [0.77] & [0.80] & [0.59] & [0.68] \\
\hline \multirow[t]{2}{*}{ Trade Union } & -1.03 & -1.02 & -0.98 & -1.49 & -1.25 & -0.98 & -0.9 & -0.39 & -0.79 & $-1.50 * *$ & -0.52 \\
\hline & {$[0.79]$} & [0.91] & {$[0.75]$} & [1.02] & [1.41] & [0.91] & [1.32] & [0.92] & [1.09] & [0.62] & [1.12] \\
\hline Observations & 112628 & 64457 & 48171 & 10886 & 10878 & 15273 & 13285 & 14135 & 16814 & 17572 & 13785 \\
\hline \multicolumn{12}{|c|}{ Heckman } \\
\hline \multicolumn{12}{|l|}{ Heckman 2nd } \\
\hline \multirow[t]{2}{*}{ Civil Associations } & $-2.70 * * *$ & $-2.37 * * *$ & $-3.19 * * *$ & $-1.95 * * *$ & $-1.90 * *$ & $-3.52 * * *$ & $-2.12 * * *$ & $-2.30 * * *$ & $-2.53 * * *$ & $-3.35 * * *$ & $-3.83 * * *$ \\
\hline & [0.35] & [0.53] & [0.43] & [0.57] & [0.89] & [0.77] & [0.73] & [0.67] & [0.65] & {$[0.50]$} & [0.55] \\
\hline \multirow[t]{2}{*}{ Trade Union } & -0.85 & -0.84 & -0.83 & -1.04 & -0.95 & -0.94 & -0.77 & -0.33 & -0.62 & $-1.31 * *$ & -0.46 \\
\hline & {$[0.66]$} & {$[0.75]$} & {$[0.64]$} & {$[0.74]$} & [1.02] & [0.89] & [1.11] & {$[0.76]$} & [0.89] & {$[0.56]$} & [1.02] \\
\hline \multicolumn{12}{|l|}{ Heckman 1st } \\
\hline \multirow[t]{2}{*}{ "Don't know" } & $-0.53 * * *$ & $-0.55 * * *$ & $-0.50 * * *$ & $-0.51 * * *$ & $-0.59 * * *$ & $-0.53 * * *$ & $-0.56 * * *$ & $-0.54 * * *$ & $-0.55 * * *$ & $-0.45 * * *$ & $-0.53 * * *$ \\
\hline & [0.03] & [0.04] & [0.02] & [0.04] & [0.04] & [0.06] & [0.07] & [0.05] & [0.07] & {$[0.04]$} & [0.04] \\
\hline Observations & 177932 & 110245 & 67687 & 22103 & 20746 & 21617 & 22291 & 23488 & 25407 & 23564 & 18716 \\
\hline \multicolumn{12}{|c|}{ Panel B. Using sectoral union membership rates in UK as IV } \\
\hline \multicolumn{12}{|c|}{ OLS } \\
\hline \multicolumn{12}{|l|}{ 2nd stage - } \\
\hline \multirow[t]{2}{*}{ Civil Associations } & $-2.59 * * *$ & $-2.11 * *$ & $-3.29 * * *$ & -2.01 & -2.08 & $-2.45 * *$ & $-1.78 * *$ & $-2.24 * *$ & $-2.62 * * *$ & $-3.75 * * *$ & $-3.50 * * *$ \\
\hline & [0.61] & {$[0.85]$} & [0.75] & [1.13] & [1.23] & [0.96] & {$[0.80]$} & [0.77] & [0.87] & [0.85] & [0.88] \\
\hline Trade Union & -6.98 & -4.84 & $-10.71 * *$ & -0.71 & -5.66 & -7.32 & -5.46 & -5.12 & -6.34 & $-11.59 *$ & $-15.35^{*}$ \\
\hline & {$[4.09]$} & [5.04] & [4.31] & [4.37] & {$[6.50]$} & {$[4.13]$} & {$[8.22]$} & [7.27] & {$[6.12]$} & [5.85] & [7.45] \\
\hline Observations & 116471 & 71344 & 45127 & 13942 & 12823 & 14442 & 14756 & 15381 & 16829 & 15543 & 12755 \\
\hline & & & & & Probit & & & & & & \\
\hline 2nd stage - & & & & & & & & & & & \\
\hline Civil Associations & $-3.30 * * *$ & $-2.98 * * *$ & $-3.71 * * *$ & $-2.77 * * *$ & $-2.70 * *$ & $-4.08 * * *$ & $-2.58 * * *$ & $-2.64 * * *$ & $-2.93 * * *$ & $-4.07 * * *$ & $-4.17 * * *$ \\
\hline & {$[0.50]$} & [0.73] & [0.59] & [0.98] & [1.24] & [1.02] & [0.90] & [0.80] & [0.81] & [0.67] & [0.68] \\
\hline Trade Union & $-8.00 *$ & -5.62 & $-12.03 * * *$ & -0.65 & -5.83 & $-8.31 *$ & -6.79 & -6.71 & -6.52 & $-13.58 * *$ & $-17.81 * * *$ \\
\hline & {$[4.29]$} & {$[5.56]$} & [3.68] & {$[5.88]$} & [6.39] & {$[4.33]$} & {$[9.76]$} & {$[7.20]$} & [5.67] & {$[5.86]$} & [5.36] \\
\hline Observations & 102852 & 59369 & 43483 & 10021 & 10330 & 13009 & 12470 & 13539 & 15914 & 15543 & 12026 \\
\hline & & & & & Heckman & & & & & & \\
\hline Heckman 2nd & & & & & & & & & & & \\
\hline Civil Associations & $-2.96 * * *$ & $-2.57 * * *$ & $-3.25 * * *$ & $-2.15 * * *$ & $-2.27^{* *}$ & $-3.69 * * *$ & $-2.28 * * *$ & $-2.42 * * *$ & $-2.52 * * *$ & $-3.57 * * *$ & $-3.73 * * *$ \\
\hline & [0.41] & [0.60] & [0.46] & [0.66] & [0.95] & [0.91] & [0.84] & [0.76] & [0.69] & {$[0.56]$} & [0.55] \\
\hline Trade Union & $-7.22^{*}$ & -5.01 & $-10.47 * * *$ & -0.50 & -5.34 & $-7.46^{*}$ & -5.93 & -6.62 & -5.68 & $11.56^{* *}$ & $-16.04 * * *$ \\
\hline & [3.92] & [4.90] & [3.46] & [4.67] & [5.79] & [4.11] & [8.09] & [6.96] & [5.07] & [5.24] & [5.05] \\
\hline Heckman 1st & & & & & & & & & & & \\
\hline "Don't know" & $-0.55 * * *$ & $-0.58 * * *$ & $-0.51 * * *$ & $-0.55 * * *$ & $-0.63 * * *$ & $-0.55 * * *$ & $-0.59 * * *$ & $-0.57 * * *$ & $-0.57 * * *$ & $-0.45 * * *$ & $-0.56 * * *$ \\
\hline & [0.04] & [0.04] & [0.03] & [0.05] & [0.05] & [0.07] & [0.09] & [0.05] & [0.08] & [0.04] & [0.03] \\
\hline Observations & 154298 & 94323 & 59975 & 18077 & 17643 & 18653 & 19307 & 20643 & 22498 & 20952 & 16525 \\
\hline IV 1st - Stage & & & & & & & & & & & \\
\hline UK UM & $0.36 * * *$ & $0.39 * * *$ & $0.31 * * *$ & $0.43 * * *$ & $0.44 * * *$ & $0.43 * * *$ & $0.33 * * *$ & $0.33 * * *$ & $0.29 * * *$ & $0.30 * * *$ & $0.34 * * *$ \\
\hline & [0.01] & [0.01] & [0.01] & [0.02] & [0.02] & [0.02] & [0.02] & [0.02] & [0.02] & [0.02] & [0.02] \\
\hline
\end{tabular}

Note. See notes to Table 6. 
Table 8. Drivers of Populist Party Vote. Probit Estimates. Robustness to Outliers

\begin{tabular}{|c|c|c|c|c|c|c|c|c|c|c|c|}
\hline & [1] & {$[2]$} & [3] & {$[4]$} & {$[5]$} & {$[6]$} & [7] & {$[8]$} & [9] & [10] & [11] \\
\hline & All & Pre-2010 & Post-2012 & 2002 & 2004 & 2006 & 2008 & 2010 & 2012 & 2014 & 2016 \\
\hline \multicolumn{12}{|c|}{ Country Excluded } \\
\hline \multicolumn{12}{|c|}{ Coefficient on civil associations } \\
\hline \multirow[t]{2}{*}{ None } & $-2.74 * * *$ & $-2.42 * * *$ & $-3.22 * * *$ & $-2.03 * * *$ & $-1.97 * *$ & $-3.57 * * *$ & $-2.14 * * *$ & $-2.31 * * *$ & $-2.56 * * *$ & $-3.38 * * *$ & $-3.85 * * *$ \\
\hline & {$[0.36]$} & {$[0.55]$} & {$[0.42]$} & {$[0.60]$} & {$[0.86]$} & [0.83] & {$[0.73]$} & {$[0.66]$} & [0.64] & [0.49] & {$[0.56]$} \\
\hline \multirow[t]{2}{*}{ Austria } & $-3.30 * * *$ & $-3.06 * * *$ & $-3.59 * * *$ & $-3.07 * * *$ & $-2.91 * *$ & $-3.99 * * *$ & $-2.53 * * *$ & $-2.73 * * *$ & $-3.12 * * *$ & $-3.89 * * *$ & $-3.75 * * *$ \\
\hline & {$[0.50]$} & {$[0.75]$} & [0.57] & [1.07] & [1.36] & [0.99] & [0.86] & [0.76] & [0.79] & [0.58] & [0.69] \\
\hline \multirow[t]{2}{*}{ Belgium } & $-3.53 * * *$ & $-3.11 * * *$ & $-4.03 * * *$ & $-2.84^{* *}$ & $-2.71 * *$ & $-4.34 * * *$ & $-2.80 * * *$ & $-2.68 * * *$ & $-3.35 * * *$ & $-4.13 * * *$ & $-4.67 * * *$ \\
\hline & [0.49] & [0.75] & [0.58] & [1.13] & [1.29] & [0.72] & [0.94] & [0.82] & [0.86] & [0.61] & [0.74] \\
\hline \multirow[t]{2}{*}{ Bulgaria } & $-3.31 * * *$ & $-2.93 * * *$ & $-3.78 * * *$ & $-2.91 * * *$ & $-2.62 * *$ & $-3.52 * * *$ & $-2.44 * * *$ & $-2.94 * * *$ & $-3.28 * * *$ & $-3.83 * * *$ & $-4.24 * * *$ \\
\hline & [0.48] & [0.72] & {$[0.56]$} & [0.97] & [1.24] & [0.86] & [0.87] & [0.80] & [0.83] & [0.58] & [0.68] \\
\hline \multirow[t]{2}{*}{ Switzerland } & $-3.08 * * *$ & $-2.74 * * *$ & $-3.50 * * *$ & $-2.51 * *$ & $-2.44 * *$ & $-3.41 * * *$ & $-2.54 * * *$ & $-2.55 * * *$ & $-2.69 * * *$ & $-3.60 * * *$ & $-4.24 * * *$ \\
\hline & {$[0.50]$} & [0.76] & [0.55] & [1.08] & [1.24] & [0.94] & [0.91] & {$[0.80]$} & {$[0.76]$} & [0.59] & [0.68] \\
\hline \multirow[t]{2}{*}{ Czech } & $-3.32 * * *$ & $-2.95 * * *$ & $-3.82 * * *$ & $-2.91 * * *$ & $-2.62 * *$ & $-3.69 * * *$ & $-2.53 * * *$ & $-2.73 * * *$ & $-3.12 * * *$ & $-3.96 * * *$ & $-4.47 * * *$ \\
\hline & [0.48] & {$[0.70]$} & [0.57] & [0.97] & [1.24] & [0.87] & [0.86] & {$[0.76]$} & [0.79] & [0.60] & [0.74] \\
\hline \multirow[t]{2}{*}{ Germany } & $-3.58 * * *$ & $-3.27 * * *$ & $-3.95 * * *$ & $-2.91 * * *$ & $-3.19 * *$ & $-4.07 * * *$ & $-2.82 * * *$ & $-3.10 * * *$ & $-3.55 * * *$ & $-3.93 * * *$ & $-4.42 * * *$ \\
\hline & [0.54] & [0.79] & [0.64] & [0.97] & {$[1.46]$} & [1.00] & [1.00] & [0.88] & [0.89] & [0.69] & [0.81] \\
\hline \multirow[t]{2}{*}{ Denmark } & $-3.13 * * *$ & $-2.58 * * *$ & $-3.78 * * *$ & $-2.86 * * *$ & $-2.41 *$ & $-3.26 * * *$ & $-1.87 * * *$ & $-2.20 * * *$ & $-3.26 * * *$ & $-3.84 * * *$ & $-4.24 * * *$ \\
\hline & [0.50] & [0.74] & [0.57] & [1.06] & [1.43] & [0.84] & [0.69] & [0.67] & [0.86] & [0.62] & [0.68] \\
\hline \multirow[t]{2}{*}{ Finland } & $-3.20 * * *$ & $-3.20 * * *$ & $-3.20 * * *$ & $-3.24 * * *$ & $-2.80 *$ & $-3.73 * * *$ & $-3.01 * * *$ & $-2.92 * * *$ & $-2.69 * * *$ & $-3.23 * * *$ & $-3.69 * * *$ \\
\hline & [0.53] & [0.80] & [0.46] & [1.10] & [1.47] & [0.93] & [0.95] & [0.87] & [0.89] & [0.38] & [0.67] \\
\hline \multirow[t]{2}{*}{ France } & $-3.28 * * *$ & $-2.99 * * *$ & $-3.64 * * *$ & $-2.91 * * *$ & $-2.62 * *$ & $-3.67 * * *$ & $-2.75 * * *$ & $-2.77 * * *$ & $-3.12 * * *$ & $-3.83 * * *$ & $-3.97 * * *$ \\
\hline & [0.50] & [0.74] & [0.58] & [0.97] & [1.24] & [0.94] & [0.94] & [0.81] & [0.84] & [0.60] & [0.71] \\
\hline \multirow[t]{2}{*}{ UK } & $-3.30 * * *$ & $-3.00 * * *$ & $-3.68 * * *$ & $-2.91 * * *$ & $-2.62 * *$ & $-3.99 * * *$ & $-2.53 * * *$ & $-2.73 * * *$ & $-3.12 * * *$ & $-3.81 * * *$ & $-4.19 * * *$ \\
\hline & [0.49] & [0.72] & [0.56] & [0.97] & [1.24] & [0.96] & [0.86] & {$[0.76]$} & [0.79] & [0.60] & [0.72] \\
\hline \multirow[t]{2}{*}{ Hungary } & $-3.17 * * *$ & $-2.88 * * *$ & $-3.54 * * *$ & $-2.91 * * *$ & $-2.62 * *$ & $-3.44 * * *$ & $-2.48 * * *$ & $-2.77 * * *$ & $-2.88 * * *$ & $-3.57 * * *$ & $-4.24 * * *$ \\
\hline & [0.46] & [0.66] & [0.54] & [0.97] & [1.24] & [0.79] & [0.79] & [0.73] & [0.77] & [0.57] & [0.68] \\
\hline \multirow[t]{2}{*}{ Italy } & $-3.27 * * *$ & $-2.95 * * *$ & $-3.66 * * *$ & $-2.96 * * *$ & $-2.62 * *$ & $-3.69 * * *$ & $-2.53 * * *$ & $-2.73 * * *$ & $-2.92 * * *$ & $-3.83 * * *$ & $-4.24 * * *$ \\
\hline & [0.48] & [0.71] & [0.55] & [1.03] & [1.24] & [0.87] & [0.86] & [0.76] & [0.80] & [0.58] & [0.68] \\
\hline \multirow[t]{2}{*}{ Lithuania } & $-3.36 * * *$ & $-2.95 * * *$ & $-3.89 * * *$ & $-2.91 * * *$ & $-2.62 * *$ & $-3.69 * * *$ & $-2.53 * * *$ & $-2.73 * * *$ & $-3.35 * * *$ & $-4.07 * * *$ & $-4.24 * * *$ \\
\hline & [0.48] & [0.70] & [0.56] & [0.97] & [1.24] & [0.87] & [0.86] & [0.76] & [0.82] & [0.61] & [0.68] \\
\hline \multirow[t]{2}{*}{ Netherlands } & $-3.58 * * *$ & $-3.34 * * *$ & $-3.86 * * *$ & $-3.79 * * *$ & $-3.17^{* *}$ & $-4.07 * * *$ & $-2.87 * * *$ & $-2.68 * * *$ & $-3.31 * * *$ & $-3.85 * * *$ & $-4.50 * * *$ \\
\hline & [0.49] & [0.76] & [0.59] & [1.04] & [1.39] & [0.98] & [0.98] & {$[0.86]$} & [0.86] & [0.65] & {$[0.70]$} \\
\hline \multirow[t]{2}{*}{ Norway } & $-2.88 * * *$ & $-2.15^{* * *}$ & $-3.73 * * *$ & $-1.54 * *$ & $-1.12^{*}$ & $-3.09 * * *$ & $-2.21 * *$ & $-2.39 * * *$ & $-2.96 * * *$ & $-3.97 * * *$ & $-4.31 * * *$ \\
\hline & [0.47] & [0.57] & [0.60] & {$[0.71]$} & {$[0.58]$} & [0.95] & {$[0.96]$} & [0.84] & [0.89] & [0.58] & [0.77] \\
\hline \multirow[t]{2}{*}{ Poland } & $-3.29 * * *$ & $-2.95 * * *$ & $-3.72 * * *$ & $-3.37 * * *$ & $-2.84 * *$ & $-3.40 * * *$ & $-2.02 * *$ & $-2.94 * * *$ & $-3.35 * * *$ & $-3.80 * * *$ & $-4.05 * * *$ \\
\hline & [0.36] & [0.63] & [0.41] & {$[0.80]$} & [1.23] & [0.82] & [0.81] & [0.55] & [0.57] & [0.53] & [0.58] \\
\hline \multirow[t]{2}{*}{ Sweden } & $-3.33 * * *$ & $-2.97 * * *$ & $-3.82 * * *$ & $-2.91 * * *$ & $-2.62 * *$ & $-3.69 * * *$ & $-2.53 * * *$ & $-2.83 * * *$ & $-2.94 * * *$ & $-3.99 * * *$ & $-4.57 * * *$ \\
\hline & [0.51] & [0.72] & [0.62] & [0.97] & [1.24] & [0.87] & [0.86] & [0.85] & [0.86] & [0.65] & [0.73] \\
\hline
\end{tabular}

Notes. This table reports coefficient estimates from the Probit for key variables only, with one country excluded at the time. All regressions include the controls in Table 1. The coefficient estimates in all the specifications indicate marginal effects. ${ }^{* * *},{ }^{* *}$, and $*$ denote statistical significance at 1,5 , and 10 percent levels, respectively. Note that we do not report estimates from the Heckman model as the estimates from several specifications fail to converge. 
Table 9. Heterogeneity in the Relationship between Populist Vote and Association Membership

\begin{tabular}{|c|c|c|c|c|c|c|c|c|c|c|c|}
\hline & [1] & [2] & [3] & [4] & [5] & [6] & [7] & [8] & [9] & [10] & [11] \\
\hline & All & Pre-2010 & Post-2012 & 2002 & 2004 & 2006 & 2008 & 2010 & 2012 & 2014 & 2016 \\
\hline & \multicolumn{11}{|c|}{ Panel A. By Age Group } \\
\hline \multicolumn{12}{|l|}{ Young } \\
\hline \multirow[t]{2}{*}{ OLS } & $-2.51 * * *$ & -1.93 & $-3.41 * * *$ & $-2.22 *$ & $-2.52 *$ & -2.4 & -1.56 & -0.77 & $-4.66 * *$ & $-2.99 *$ & -2.46 \\
\hline & [0.85] & [1.17] & [0.85] & [1.23] & [1.35] & [1.95] & [1.05] & [1.66] & [1.81] & [1.41] & [1.74] \\
\hline \multirow[t]{2}{*}{ Probit } & $-3.56 * * *$ & $-3.16 * *$ & $-4.14 * * *$ & $-4.49 * * *$ & -3.62 & -3.98 & $-2.59 *$ & -1.24 & $-5.44 * *$ & $-3.78 * *$ & -3.13 \\
\hline & [0.85] & [1.36] & [0.96] & [1.46] & {$[2.34]$} & {$[2.71]$} & {$[1.44]$} & {$[2.13]$} & [2.43] & [1.75] & [2.09] \\
\hline \multirow[t]{2}{*}{ Heckman } & $-2.70 * * *$ & $-2.30 * *$ & $-3.46 * * *$ & $-1.66 * * *$ & -3.9 & -3.49 & $-1.69 * *$ & -0.98 & $-4.91 * *$ & $-3.55^{* *}$ & -2.08 \\
\hline & [0.69] & [0.93] & [0.86] & [0.47] & {$[2.47]$} & [3.00] & [0.79] & {$[1.60]$} & [2.49] & [1.45] & [1.36] \\
\hline \multicolumn{12}{|l|}{ Middle } \\
\hline \multirow[t]{2}{*}{ OLS } & $-2.35 * * *$ & $-1.92 * *$ & $-3.05 * * *$ & -1.65 & -2.45 & $-2.36 * *$ & $-1.22^{*}$ & $-1.92 * *$ & $-2.05^{*}$ & $-3.80 * * *$ & $-3.31 * * *$ \\
\hline & [0.51] & [0.71] & [0.70] & [0.95] & [1.43] & [0.83] & {$[0.69]$} & [0.84] & [0.99] & [0.76] & [0.89] \\
\hline \multirow[t]{2}{*}{ Probit } & $-3.01 * * *$ & $-2.71 * * *$ & $-3.43 * * *$ & $-2.25 * * *$ & $-3.24 * *$ & $-3.93 * * *$ & $-1.68 *$ & $-2.36 * *$ & $-2.18^{* *}$ & $-4.07 * * *$ & $-4.04 * * *$ \\
\hline & [0.48] & [0.65] & [0.65] & [0.86] & [1.30] & [0.98] & {$[0.92]$} & [1.04] & [1.09] & [0.64] & [0.83] \\
\hline \multirow[t]{2}{*}{ Heckman } & $-2.52 * * *$ & $-2.15^{* * *}$ & $-3.15^{* * *}$ & $-1.68 * * *$ & $-2.23 * * *$ & $-3.64 * * *$ & $-1.42^{*}$ & $-1.84 * *$ & $-1.95^{*}$ & $-3.77 * * *$ & $-4.01 * * *$ \\
\hline & [0.40] & [0.52] & [0.53] & [0.60] & [0.85] & [0.91] & {$[0.82]$} & {$[0.85]$} & [1.00] & [0.61] & [0.82] \\
\hline \multicolumn{12}{|l|}{ Old } \\
\hline \multirow[t]{2}{*}{ OLS } & $-2.91 * * *$ & $-2.25 * *$ & $-3.71 * * *$ & -2.74 & -0.06 & -1.59 & $-2.97^{*}$ & $-3.56 * * *$ & $-3.50 * * *$ & $-3.45 * * *$ & $-4.25 * * *$ \\
\hline & [0.75] & [0.95] & [0.94] & [1.80] & [1.21] & [1.13] & [1.55] & [0.91] & [1.06] & [1.08] & [1.29] \\
\hline \multirow[t]{2}{*}{ Probit } & $-3.88 * * *$ & $-3.39 * * *$ & $-4.35 * * *$ & $-4.49 * *$ & 0.23 & $-2.49 * *$ & $-5.58 * * *$ & $-4.55^{* * *}$ & $-4.31 * * *$ & $-3.87 * * *$ & $-5.05 * * *$ \\
\hline & [0.61] & [0.83] & [0.76] & [1.91] & [1.91] & [1.25] & [2.16] & [0.80] & [0.95] & [0.98] & [1.32] \\
\hline \multirow[t]{3}{*}{ Heckman } & $-3.40 * * *$ & & $-3.85 * * *$ & $-2.82 * *$ & 0.13 & $-2.70 * *$ & $-4.26 * * *$ & $-4.10 * * *$ & $-3.41 * * *$ & $-3.81 * * *$ & $-5.01 * * *$ \\
\hline & [0.55] & & [0.75] & [1.13] & [1.52] & [1.33] & [1.56] & [0.71] & [0.75] & [1.13] & [1.49] \\
\hline & & & & & Panel B & By Educati & n Group & & & & \\
\hline \multicolumn{12}{|l|}{ Below Sec. } \\
\hline \multirow[t]{2}{*}{ OLS } & $-3.21 * * *$ & $-1.76 * *$ & $-6.16 * * *$ & -1.72 & -0.07 & -0.68 & -2.62 & $-3.78 *$ & $-4.20 * *$ & $-8.26 * * *$ & $-5.74 *$ \\
\hline & [0.92] & [0.75] & [1.39] & [1.05] & [1.19] & [2.26] & [1.75] & [2.08] & [1.72] & [2.55] & [3.10] \\
\hline \multirow[t]{2}{*}{ Probit } & $-5.04 * * *$ & $-3.34 * *$ & $-7.48 * * *$ & $-3.15^{* *}$ & -0.23 & -1.54 & -4.76 & $-5.98^{*}$ & $-5.03 * *$ & $-9.49 * * *$ & $-7.34 *$ \\
\hline & [1.32] & [1.49] & [1.43] & [1.43] & [3.16] & [4.21] & [3.21] & [3.23] & [2.31] & [2.82] & [3.83] \\
\hline \multirow[t]{2}{*}{ Heckman } & $-3.79 * * *$ & & & $-2.05^{* *}$ & 0.03 & -2.32 & -3.15 & $-4.43 * *$ & $-2.74 * *$ & $-9.33 * * *$ & -4.73 \\
\hline & [0.98] & & & [0.92] & [1.18] & [5.47] & [2.61] & [2.11] & [1.31] & [2.61] & [3.00] \\
\hline \multicolumn{12}{|l|}{ Secondary } \\
\hline \multirow[t]{2}{*}{ OLS } & $-3.28 * * *$ & $-2.49 * *$ & $-4.60 * * *$ & -2.27 & -2.62 & $-3.22 * *$ & -1.23 & $-3.07 * *$ & $-3.94 * * *$ & $-4.95^{* * *}$ & $-4.99 * * *$ \\
\hline & [0.84] & [1.17] & [1.01] & [1.50] & [1.73] & [1.16] & [1.04] & [1.15] & [1.25] & [1.17] & [1.01] \\
\hline \multirow[t]{2}{*}{ Probit } & $-4.19 * * *$ & $-3.42 * * *$ & $-5.22 * * *$ & $-2.93 * *$ & $-3.50 *$ & $-4.80 * * *$ & -1.55 & $-3.85^{* * *}$ & $-4.59 * * *$ & $-5.34 * * *$ & $-5.82 * * *$ \\
\hline & [0.65] & [1.03] & [0.78] & [1.46] & [1.86] & [1.04] & [1.42] & [1.09] & [1.05] & [1.02] & [0.77] \\
\hline Heckman & $-3.27 * * *$ & $-2.60 * * *$ & $-4.35 * * *$ & $-1.97^{* *}$ & $-2.63^{*}$ & $-4.31 * * *$ & -1.23 & $-3.02 * * *$ & $-3.70 * * *$ & $-4.45^{* * *}$ & $-5.09 * * *$ \\
\hline & [0.47] & [0.75] & [0.66] & [0.85] & {$[1.40]$} & [0.93] & [1.12] & [0.83] & [0.91] & [0.87] & [0.72] \\
\hline Tertia & & & & & & & & & & & \\
\hline OLS & $-1.27^{* * *}$ & $-1.36 * *$ & $-1.14 * *$ & $-1.57^{*}$ & -1.06 & $-1.32 *$ & $-2.04 * * *$ & -0.79 & -0.68 & $-1.10 *$ & $-1.65 * *$ \\
\hline & [0.34] & [0.47] & [0.44] & [0.87] & {$[0.70]$} & {$[0.65]$} & [0.66] & {$[0.56]$} & {$[0.79]$} & {$[0.57]$} & [0.72] \\
\hline Probit & $-1.67 * * *$ & $-2.08 * * *$ & $-1.29 * * *$ & $-2.51 * * *$ & $-1.80 *$ & $-2.09 * *$ & $-3.17 * * *$ & -1.07 & -0.92 & $-1.08 * *$ & $-1.89 * * *$ \\
\hline & [0.34] & [0.49] & [0.44] & [0.78] & [1.01] & [0.85] & [0.69] & {$[0.70]$} & {$[0.81]$} & [0.52] & [0.70] \\
\hline Heckman & & & $-1.15^{* * *}$ & $-1.47 * *$ & $-1.18^{*}$ & $-1.55^{* *}$ & $-2.69 * * *$ & -0.86 & -0.8 & $-0.92^{*}$ & $-2.04 * *$ \\
\hline & & & [0.42] & [0.58] & {$[0.63]$} & [0.63] & [0.61] & [0.55] & [0.69] & {$[0.47]$} & [1.02] \\
\hline
\end{tabular}

Note. This table reports coefficient estimates for key variables only. All regressions include the controls in Table 1. The coefficient estimates in Probit and Heckman specifications indicate marginal effects. ${ }^{* *},{ }^{* *}$, and $*$ denote statistical significance at 1,5 , and 10 percent levels, respectively. 
Table 10. Probit Estimates of Drivers of Populist Party Vote: Latin America

\begin{tabular}{|c|c|c|c|c|c|c|c|c|c|c|}
\hline & $\begin{array}{l}{[1]} \\
\text { All } \\
\end{array}$ & 1996, 98 & $\begin{array}{c}{[3]} \\
2005,07 \\
08\end{array}$ & $\begin{array}{c}{[4]} \\
1996,98 \\
2005 \\
\end{array}$ & 2007,08 & 1996 & 1998 & 2005 & 2007 & 2008 \\
\hline \multirow[t]{2}{*}{ Union Member } & -0.53 & 0.37 & -0.76 & $2.06 * *$ & $-2.42 * *$ & -1.41 & 1.97 & $3.60 * * *$ & $-2.85^{* *}$ & -2.09 \\
\hline & [0.91] & [1.06] & [1.01] & [0.88] & [1.06] & [2.19] & [1.73] & {$[0.74]$} & [1.15] & [1.54] \\
\hline \multirow[t]{2}{*}{ Income Sufficient } & -0.58 & $-4.99 * * *$ & 0.63 & $-1.91 * * *$ & 0.46 & $-9.66 * * *$ & -2.56 & 0.93 & 2.09 & -1.27 \\
\hline & [1.29] & [1.63] & {$[1.50]$} & {$[0.68]$} & [1.96] & {$[2.75]$} & {$[3.40]$} & [1.33] & [1.96] & {$[2.72]$} \\
\hline \multirow[t]{2}{*}{ Income Difficult } & $1.68 * *$ & $3.28 * * *$ & 1.06 & $2.28 * * *$ & 1.24 & $4.21 * * *$ & $2.68 * * *$ & 0.43 & 0.82 & 1.59 \\
\hline & {$[0.76]$} & {$[0.78]$} & {$[0.80]$} & {$[0.68]$} & {$[1.05]$} & [1.63] & {$[0.88]$} & [1.35] & [1.25] & [1.53] \\
\hline \multirow[t]{2}{*}{ Female } & -0.67 & $-2.43^{*}$ & -0.1 & -1.18 & -0.27 & -1.58 & $-2.91 * *$ & 0.45 & -0.04 & -0.48 \\
\hline & [0.81] & [1.27] & [0.90] & [0.97] & [0.92] & [4.67] & [1.16] & [1.79] & [1.04] & [1.07] \\
\hline \multirow[t]{2}{*}{ Young } & 1.84 & 2.48 & 1.61 & 1.52 & 2.17 & 2.66 & 2.23 & 0.25 & -0.45 & $4.17^{* *}$ \\
\hline & {$[1.16]$} & [1.78] & {$[1.15]$} & {$[1.23]$} & {$[1.44]$} & [3.01] & [1.62] & [1.29] & [1.16] & {$[2.04]$} \\
\hline \multirow[t]{2}{*}{ Old } & $-3.47 * *$ & $-14.91 * * *$ & -1.89 & $-6.34 * * *$ & -2.15 & $-17.23 * * *$ & $-13.25 * * *$ & -1.28 & -5.44 & 0.16 \\
\hline & {$[1.65]$} & [1.42] & {$[1.70]$} & {$[1.24]$} & {$[1.85]$} & [4.19] & [3.57] & {$[2.19]$} & {$[3.71]$} & {$[2.46]$} \\
\hline \multirow[t]{2}{*}{ Secondary Education } & 1.8 & 3.32 & 1.17 & 2.81 & 0.99 & 3.7 & $2.99 * * *$ & 1.71 & 1.25 & 0.64 \\
\hline & {$[1.16]$} & {$[2.29]$} & [1.28] & [1.83] & [1.39] & [6.02] & {$[0.96]$} & [1.98] & {$[2.57]$} & [1.53] \\
\hline \multirow[t]{2}{*}{ Tertiary Education } & 0.77 & -3.18 & 2.26 & 1.05 & 0.5 & -5.72 & -1.27 & $7.18^{*}$ & -0.12 & 0.98 \\
\hline & {$[2.86]$} & [4.61] & {$[3.36]$} & [3.68] & {$[3.21]$} & [11.25] & {$[2.35]$} & [4.11] & {$[4.00]$} & [3.28] \\
\hline Country*Year FE & $\mathrm{Y}$ & $\mathrm{Y}$ & Y & $\mathrm{Y}$ & $Y$ & $Y$ & $Y$ & $Y$ & $Y$ & $Y$ \\
\hline Obs. & 18736 & 4584 & 14152 & 8236 & 10500 & 1890 & 2694 & 3652 & 4453 & 6047 \\
\hline
\end{tabular}

Notes. The dependent variable in all regressions is a dummy=1 if the individual votes for a populist party, and 0 otherwise. "Union member" takes a value of 1 if the individual is a member of a union, or any other organization, and 0 otherwise. "Income sufficient" takes a value of 1 if the individual responds that is income is sufficient, and 0 otherwise. "Income difficult" takes a value of 1 if the individual responds to be in a difficult income situation, and 0 otherwise. "Young", takes a value of 1 if the individual is less than 30 years of age, and 0 otherwise. "Old" takes a value of 1 if the individual is 65 years or older, and 0 otherwise. "Secondary education" takes a value of 1 if the individual has attained secondary education, with 12 or more years of completed schooling, and 0 otherwise. "Tertiary education" takes a value of 1 if the individual has attained tertiary education, with 16 or more years of completed schooling. The standard errors in all regressions are clustered at the country-level. $* * *, * *$, and $*$ denote statistical significance at 1,5 , and 10 percent levels, respectively. 
Table 11. OLS Estimates: Populist Parties in Power and Union Membership

\begin{tabular}{|c|c|c|}
\hline \multicolumn{3}{|c|}{ Dependent variable: Union density at (country, year) level } \\
\hline Populist party in power & $\begin{array}{c}-3.23 * * * \\
(0.87)\end{array}$ & $\begin{array}{c}-3.10 * * * \\
(0.89)\end{array}$ \\
\hline Dummy for crisis & & $\begin{array}{c}2.79 \\
(2.65)\end{array}$ \\
\hline Country fixed effects & Y & Y \\
\hline Year fixed effects & $\mathrm{Y}$ & $\mathrm{Y}$ \\
\hline Observations & 506 & 506 \\
\hline R-squared & 0.76 & 0.76 \\
\hline $\begin{array}{l}\text { Notes. The dependent varia } \\
\text { "Union density" is defined } \\
\text { any other organization. "Pot } \\
\text { party in power, and } 0 \text { otherv } \\
\text { (2013). The standard errors } \\
\text { and * denote statistical signif }\end{array}$ & $\begin{array}{l}\text { ll regressions } \\
\text { are of indivi } \\
\text { rty in power } \\
\text { licators of cr } \\
\text { gressions are }\end{array}$ & $\begin{array}{l}\text { at (country } \\
\text { member o } \\
\text { f } 1 \text { if there } \\
\text { m Laeven } \\
\text { teroskedasti } \\
\text { espectively. }\end{array}$ \\
\hline
\end{tabular}

and $*$ denote statistical significance at 1,5 , and 10 percent levels, respectively.

Figure 1. Share of Union or Civil Association Members

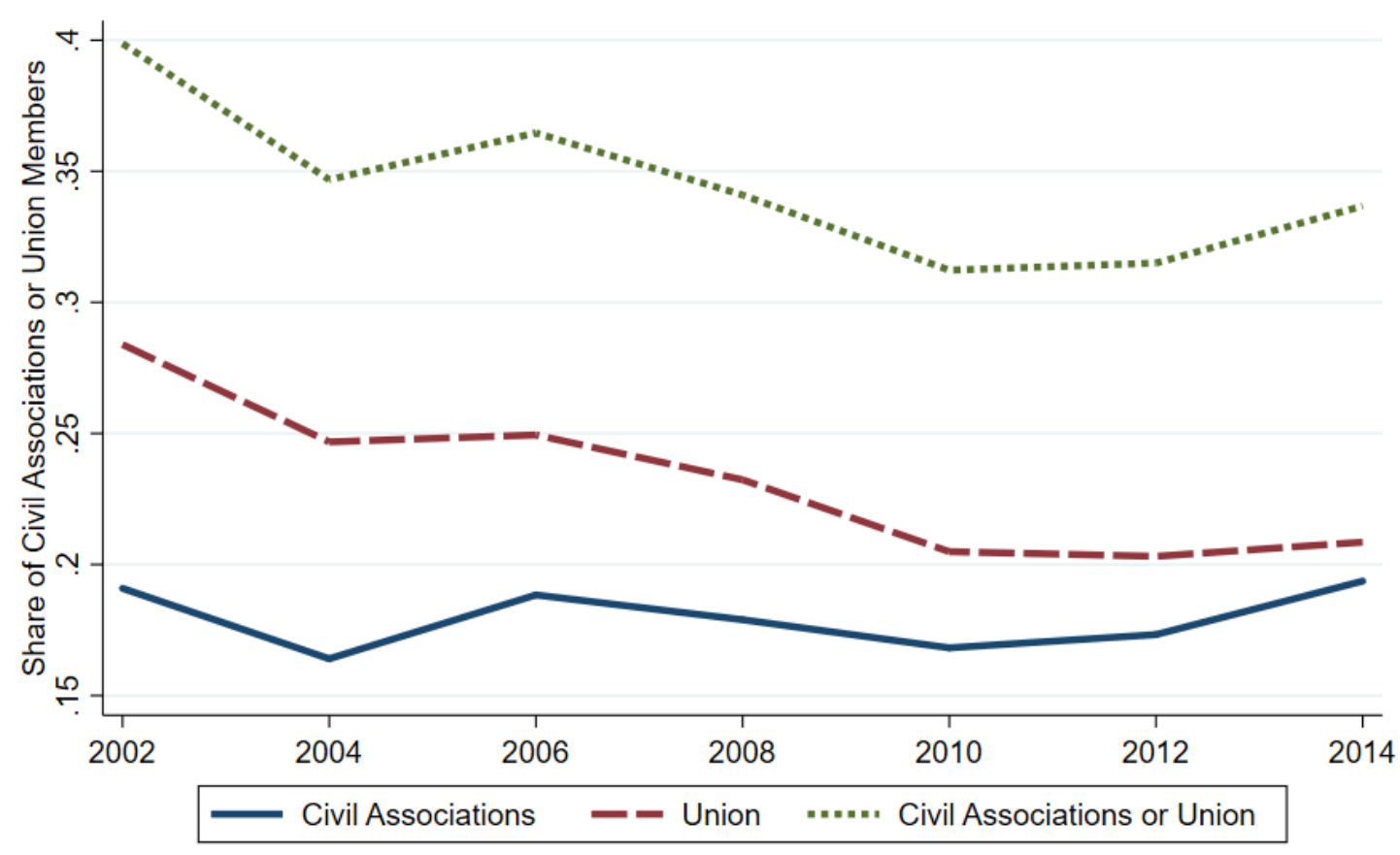


Figure 2. Compulsory Voting in the World
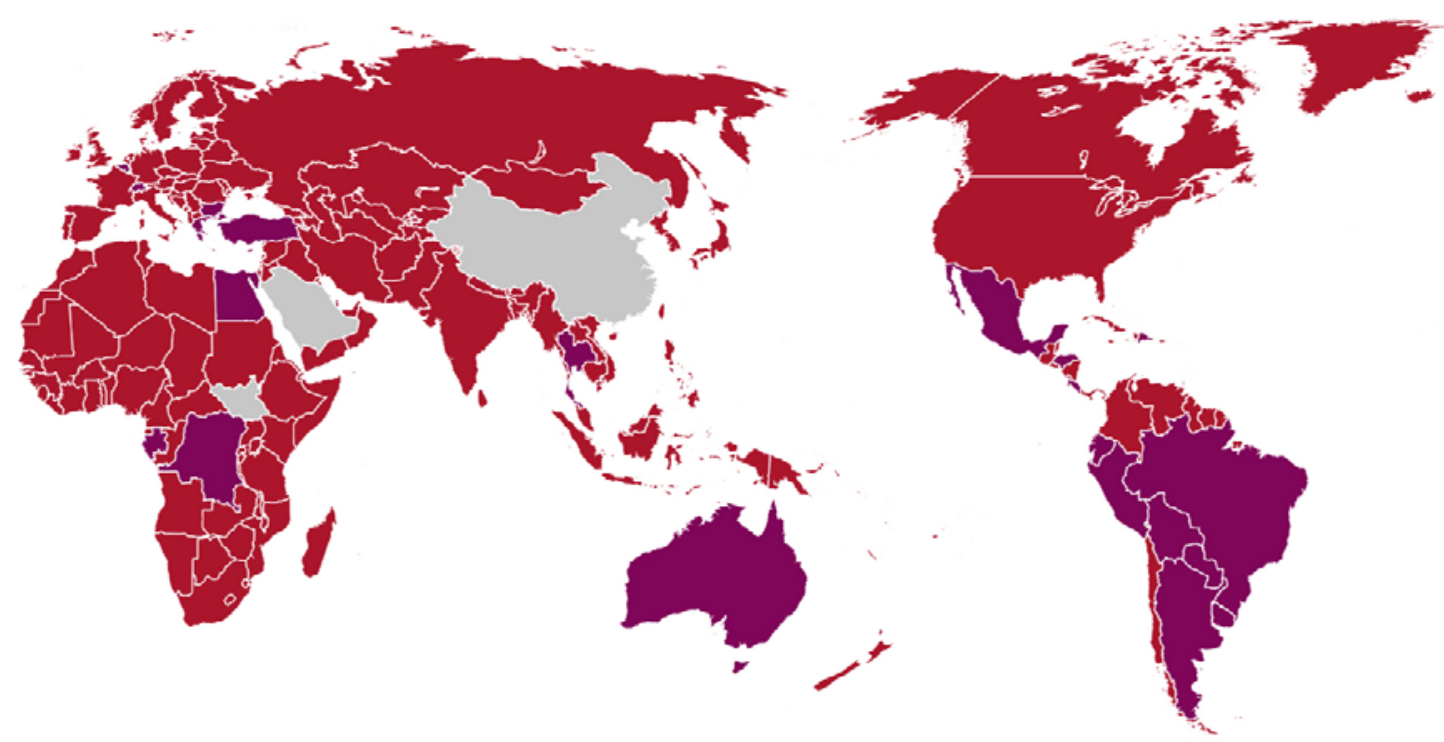

Countries with no compulsory voting

- Countries having compulsory voting

- Countries having no elections

Source: Institute for Democracy and Electoral Assistance https://www.idea.int/data-tools/data/voterturnout/compulsory-voting 
Table A1. Data Coverage

European Sample

\begin{tabular}{|c|c|c|c|c|c|c|c|c|}
\hline Country & 2002 & 2004 & 2006 & 2008 & 2010 & 2012 & 2014 & 2016 \\
\hline Austria & $Y$ & $Y$ & $Y$ & & & & $Y$ & $Y$ \\
\hline Belgium & $Y$ & $Y$ & $Y$ & $Y$ & $Y$ & $Y$ & $Y$ & $\mathrm{Y}$ \\
\hline Bulgaria & & & $Y$ & $Y$ & $Y$ & $Y$ & & \\
\hline Czech & $Y$ & $Y$ & & $Y$ & $Y$ & $Y$ & $Y$ & $Y$ \\
\hline Denmark & $Y$ & $Y$ & $Y$ & $Y$ & $Y$ & $Y$ & $Y$ & \\
\hline Finland & $Y$ & $Y$ & $Y$ & $Y$ & $Y$ & $Y$ & $Y$ & $Y$ \\
\hline France & & & $Y$ & $Y$ & $Y$ & $Y$ & $Y$ & $Y$ \\
\hline Germany & $Y$ & $Y$ & $Y$ & $Y$ & $Y$ & $Y$ & $Y$ & $Y$ \\
\hline Hungary & $Y$ & $Y$ & $Y$ & $Y$ & $Y$ & $Y$ & $Y$ & \\
\hline Italy & & & & & & $Y$ & & \\
\hline Lithuania & & & & & $Y$ & $Y$ & $Y$ & \\
\hline Netherlands & $Y$ & $\mathrm{Y}$ & $Y$ & $\mathrm{Y}$ & $\mathrm{Y}$ & $Y$ & $Y$ & $Y$ \\
\hline Norway & $Y$ & $Y$ & $Y$ & $Y$ & $Y$ & $Y$ & $Y$ & $Y$ \\
\hline Poland & $Y$ & $Y$ & $Y$ & $Y$ & $Y$ & $Y$ & $Y$ & $Y$ \\
\hline Sweden & $Y$ & $Y$ & $Y$ & $Y$ & $\mathrm{Y}$ & $Y$ & $Y$ & $Y$ \\
\hline Switzerland & $Y$ & $Y$ & $Y$ & $Y$ & $Y$ & $Y$ & $Y$ & $Y$ \\
\hline UK & & & & & & & $Y$ & $Y$ \\
\hline
\end{tabular}


Table A1. Data Coverage (Concluded)

Latin American Sample

\begin{tabular}{|c|c|c|c|c|c|}
\hline Country & 1996 & 1998 & 2005 & 2007 & 2008 \\
\hline Argentina & $\mathrm{Y}$ & $Y$ & $Y$ & $Y$ & $\mathrm{Y}$ \\
\hline Bolivia & $Y$ & $Y$ & $\mathrm{Y}$ & $Y$ & $Y$ \\
\hline Brazil & $\mathrm{Y}$ & $Y$ & $\mathrm{Y}$ & $Y$ & $\mathrm{Y}$ \\
\hline Chile & $\mathrm{Y}$ & $Y$ & $\mathrm{Y}$ & $\mathrm{Y}$ & $Y$ \\
\hline Colombia & $Y$ & $Y$ & $Y$ & $Y$ & $Y$ \\
\hline Costa Rica & & $Y$ & $Y$ & $Y$ & $Y$ \\
\hline Dominican Rep. & & & $\mathrm{Y}$ & $Y$ & $Y$ \\
\hline Ecuador & $\mathrm{Y}$ & $Y$ & $Y$ & $Y$ & $Y$ \\
\hline El Salvador & $Y$ & $Y$ & $Y$ & $Y$ & $Y$ \\
\hline Guatemala & $Y$ & $Y$ & $Y$ & $Y$ & $Y$ \\
\hline Honduras & $Y$ & $Y$ & $\mathrm{Y}$ & $Y$ & $\mathrm{Y}$ \\
\hline Mexico & $\mathrm{Y}$ & $Y$ & $\mathrm{Y}$ & $Y$ & $\mathrm{Y}$ \\
\hline Panama & $Y$ & $Y$ & $Y$ & $Y$ & $Y$ \\
\hline Paraguay & $\mathrm{Y}$ & $Y$ & $Y$ & $Y$ & $\mathrm{Y}$ \\
\hline Peru & $\mathrm{Y}$ & $Y$ & $\mathrm{Y}$ & $\mathrm{Y}$ & $Y$ \\
\hline Uruguay & $Y$ & $Y$ & $Y$ & $\mathrm{Y}$ & $Y$ \\
\hline Venezuela & $Y$ & $Y$ & $Y$ & $Y$ & $Y$ \\
\hline
\end{tabular}


Table A2. Variables and Description

\begin{tabular}{|c|c|}
\hline Variable & Description \\
\hline Populist Vote & $\begin{array}{l}=1 \text { if someone votes to a populist party. For ESS, populist party based on } \\
\text { Inglehart and Norris list. For LAC, populist party defined as the top } \\
25 \text { percent in CHES score. }\end{array}$ \\
\hline Civil Associations & $\begin{array}{l}\text { For ESS, }=1 \text { if someone worked in a civil organization or association last } \\
12 \text { months. }\end{array}$ \\
\hline Union Member & For ESS, =1 if someone is a current union member. \\
\hline Association Member & $\begin{array}{l}\text { For LAC, =1 if individual is a member of trade or labor union, or belongs } \\
\text { to an organization/group/association related to politics, students, } \\
\text { communal, religious, culture, sport, ecology, etc. }\end{array}$ \\
\hline Income sufficient & $=1$ if someone feels living comfortably on present income. \\
\hline Income difficult & $=1$ if someone feels difficult or very difficult on present income. \\
\hline Female & $=1$ if gender is female \\
\hline Young & $=1$ if age $<30$ \\
\hline Old & $=1$ if age $>=65$ \\
\hline Secondary edu & =1 if someone finished secondary education but not tertiary education. \\
\hline Tertiary edu & $=1$ if someone finished tertiary education \\
\hline Sum Don't Know & $\begin{array}{l}\text { number of "Don't Know" to a list of } 8 \text { questions, including: } \\
\text { - TV watching, news/politics/current affairs on average } \\
\text { - How interested in politics } \\
\text { - } \text { Able to take active role in political group } \\
\text { - Confident in own ability to participate in politics } \\
\text { - Easy to take part in politics } \\
\text { - Placement on left right scale } \\
\text { - State of education in country nowadays } \\
\text { - State of health services in country nowadays }\end{array}$ \\
\hline Populist in power & $\begin{array}{l}=1 \text { if party in power is a populist party as defined in Allred, Nathaniel, } \\
\text { Kirk A. Hawkins, and Saskia P. Ruth. } 2015\end{array}$ \\
\hline Union density & $\begin{array}{l}\text { net union membership as a proportion of wage earners in employment } \\
\text { at (country, year) level, taken from Vissier(2016) }\end{array}$ \\
\hline
\end{tabular}


Table A3. Summary Statistics

\begin{tabular}{l|cc|cc}
\hline \multirow{2}{*}{ Variable } & \multicolumn{2}{|c|}{ ESS } & Mean & St. Dev. \\
\hline Populist Vote & Mean & St. Dev. & 0.22 & 0.42 \\
Civil Association & 0.13 & 0.33 & & \\
Member of Civil & 0.22 & 0.41 & 0.55 & 0.50 \\
association or union & 0.41 & 0.49 & & \\
Union only & 0.27 & 0.45 & 0.09 & 0.29 \\
Income sufficient & 0.36 & 0.48 & 0.52 & 0.50 \\
Income difficult & 0.19 & 0.39 & 0.49 & 0.50 \\
Female & 0.52 & 0.50 & 0.35 & 0.48 \\
Young & 0.12 & 0.32 & 0.08 & 0.27 \\
Old & 0.24 & 0.43 & 0.21 & 0.41 \\
Secondary education & 0.62 & 0.49 & 0.07 & 0.26 \\
Tertiary education & 0.32 & 0.47 & & \\
\hline
\end{tabular}




\section{References}

Acemoğlu Daron, Geory Egorov, and Konstantin Sonin. 2013. "A Political Theory of Populism." Quarterly Journal of Economics 128: pp. 771-805.

Albertazzi, Daniele and Duncan McDonnell. 2008. Twenty-First Century Populism. Palgrave MacMillan. Algan Yann, Sergei Guriev, Elias Papaioannou, and Evegenia Passari. 2017. "The European Trust Crisis and the Rise of Populism." Brookings Papers of Economic Activity.

Allred, Nathaniel, Kirk A. Hawkins, and Saskia P. Ruth. 2015. "The Impact of Populism on Liberal Democracy.” $8^{\circ}$ Congreso Latinoamericano de Ciencia Política, Lima, Peru.

Aslanidis, Paris. 2016. "Populist Social Movements of the Great Recession" Mobilization: International Quarterly 21: pp. 301-21.

Caplan, Bryan. 2007. The Myth of the Rational Voter: Why Democracies Choose Bad Policies. Princeton University Press.

Coffé, Hilde, Bruno Heyndels and Jan Vermeir. 2007. "Fertile grounds for extreme right-wing parties: Explaining the Vlaams Blok's electoral success, Electoral Studies 26: pp. 142-55.

de Tocqueville, Alexis. 1835. Democracy in America, edited and translated by Harvey C. Mansfield and Delba Winthrop. University of Chicago Press.

Di Tella, Torcuato S. 1965. "Populism and Reform in Latin America." In Obstacles to Changes in Latin America, edited by Claudio Véliz, pp. 47-74. London: Oxford University Press.

Di Tella, Rafael and Julio Rotemberg. 2016. Populism and the Return of the "Paranoid Style": Some Evidence and a Simple Model of Demand for Incompetence as Insurance against Elite Betrayal." NBER Working Paper No. 22975.

Dornbusch, Rudiger and Sebastian Edwards, Editors. 1991. The Macroeconomics of Populism in Latin America. Chicago University Press.

Dustmann Christian, Barry Eichegreen, Sebastian Otten, André Sapir, Guido Tabellini and Gylfi Zoega. 2017. Europe's Trust Deficit. Causes and Remedies. CEPR Press.

The European Economy Advisory Group and CESifo. 2017. EEAG Report on the European Economy no. 16: Economics of Populism. https://www.cesifogroup.de/ifoHome/presse/Pressemitteilungen/Pressemitteilungen-Archiv/2017/Q1/press20170301-EEAG.html

Funke, Manuel, Moritz Schularick and Christoph Trebesch. 2016. "Going to Extremes: Politics after Financial Crises, 1870-2014.” European Economic Review 88: pp. 227-60.

Guiso, Luigi, Helios Herrea, Massimo Morelli and Tommaso Sonno. 2017. Demand and Supply of Populism. EIEF Working Paper 17/03.

Hatton, Timothy J. 2016. "Immigration, Public Opinion and the Recession in Europe." Economic Policy 31: pp. 205-46. 
Hobbolt Sara B. and Catherine De Vries. 2016. "Turning Against the Union? The Impact of the Crisis on the Eurosceptic Vote in the 2014 European Parliament Elections." Electoral Studies 44: pp. 504-14.

Houle, Christian and Paul D. Kenny. 2016. The Political and Economic Consequences of Populist Rule in Latin America. Government and Opposition.

Inglehart, Charles and Pippa Norris. 2016. Trump, Brexit, and the Rise of Populism: Economic Have-Nots and Cultural Backlash. HKS Working Paper No. RWP16-026.

Ionescu Ghita and Ernest Gellner, eds. 1969. Populism: its Meanings and National Characteristics. London: Weidenfeld and Nicolson.

Judis, John B. 2016. The Populist Explosion: How the Great Recession Transformed American and European Politics. Columbia Global Reports.

Kaltwasser, Cristóbal Rovira, and Lina Zanotti. 2016. "The Comparative (Party) Politics of the Great Recession: Causes, Consequences and Future Research Agenda." Comparative European Politics pp. 1-14.

Kriesi, Hanspeter and Takis S. Pappas, eds. 2015. European Populism in the Shadow of the Great Recession. Colchester: ECPR Press.

Laeven, L. \& Valencia, F. 2013. IMF Econ Rev. 61: p. 225. https://doi.org/10.1057/imfer.2013.12

Mayer, N. 2014. "The Electoral Impact of the Crisis on the French Working Class." In N. Bermeo and L. Bartels (eds.) Mass Politics in Tough Times: Opinions, Votes, and Protest in the Great Recession Oxford: Oxford University Press, pp. 266-96.

Mudde, Cas. 2004. The Populist Zeitgeist. Government and Opposition. 39: pp. 541-63.

Mudde, Cas. 2007. Populist Radical Right Parties in Europe. Cambridge University Press.

Mudde, Cas, and Cristóbal Rovira Kaltwasser. 2017. Populism: A Very Short Introduction. Oxford University Press.

Müller, Jan-Werner. 2016. What is Populism? Pennsylvania University Press.

Roberts, Kenneth M. 2017. "State of the Field. Party politics in hard times: Comparatives on the European and Latin American Economic Crises.” European Journal of Political Research. 56: pp. 218-33.

Rodrik, Dani. 2017. Populism and the Economics of Globalization. Mimeo. August https://drodrik.scholar.harvard.edu/files/danirodrik/files/populism and the economics of globalization.pdf

Satyanath, Shanker, Nico Voigtländer, and Hans-Joachim Voth. 2017. "Bowling for Fascism: Social Capital and the Rise of the Nazi Party in Weimar Germany, 1919-33" Journal of Political Economy, 2017, 125(2): pp. 478-526.

J. Visser. 2016. ICTWSS Data base. version 5.1. Amsterdam: Amsterdam Institute for Advanced Labour Studies (AIAS), University of Amsterdam. September.

Viandas, Tim and Daphne Halikiopoulou. 2016. "Why Far Right Parties Do Well at Times of Crisis: The Role of Labour Market Institutions. Working Paper 2016.7 European Trade Union Institute.

CInternational Monetary Fund. Not for Redistribution 